\title{
Modellazione BIM parametrica e Trattati: analogie nella rappresentazione dell'ordine architettonico
}

\author{
Giorgia Potestà
}

\section{Abstract}

La ricerca riflette sulla possibilità di modellazione BIM parametrica dell'ordine architettonico a partire dall'analisi geometrico proporzionale dell'architettura storica. Lo studio dei trattati rinascimentali, ma soprattutto delle tavole raffiguranti le rappresentazioni dell'ordine architettonico, costituiscono spunti per la scelta e l'impostazione dei parametri per la modellazione. Punto di partenza, come per tutte le attività che riguardano la conoscenza di manufatti storico architettonici, sono le acquisizioni massive di dati, in questo caso da TLS, di supporto alla restituzione parametrica dell'ordine architettonico attraverso la modellazione per famiglie nidificate. Affinità tra il concetto di modulo e quello di parametro in termini scientifici emergono con chiarezza e costituiscono il vincolo indissolubile per la conoscenza e il disegno dell'architettura storico costruita.

\section{Parole chiave}

modellazione parametrica, HBIM, ordine architettonico, trattati.
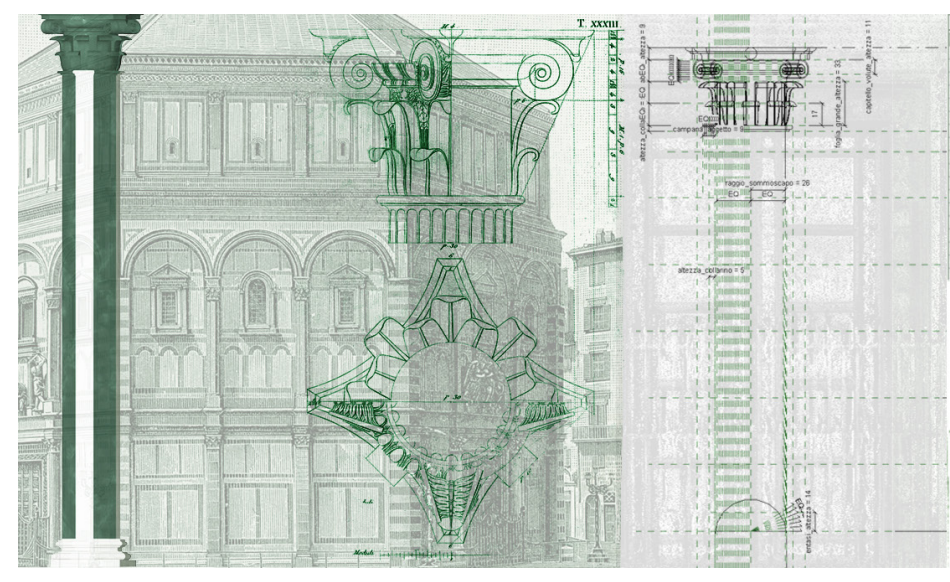

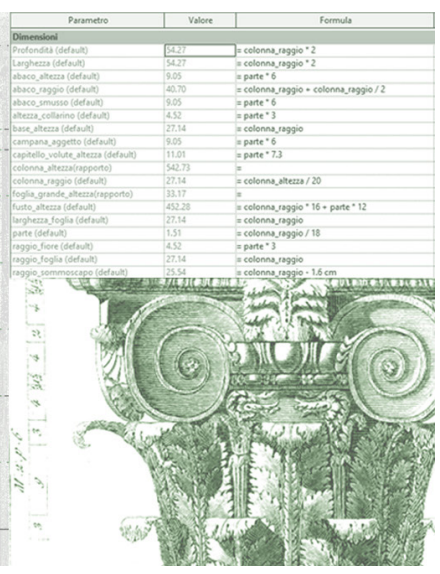




\section{Introduzione}

“Piuttosto è bene precisare cosa si intende qui per 'disegno' dell'ordine classico. [...] ma s'intenda anche l'interpretazione di questa regola, cioè la lettura della dipendenza di ogni parte rispetto all'altra e la misura dei rapporti dimensionali tra le varie parti; s'intende infine l'abbozzo di una regola generale che non è una regola, ma piuttosto una trama sulla quale imbastire il disegno, inteso come si è detto. [...] L'idea di un disegno dell'ordine nel quale siano le operazioni mentali e grafiche, il loro procedere e le loro interdipendenze, a definire il risultato a me sembra seducente, anche perché permette di superare, definitivamente, 'l'imbarazzo della regola': quale, infatti, la regola e quale il trattatista da considerare, per affrontare lo studio dell'ordine, dal momento che tutte le regole sono diverse?" [Migliaril99I, p. 49].

In effetti il Building Information Modeling è una metodologia, o meglio un processo di progettazione e documentazione degli edifici, caratterizzato dall'uso di informazioni internamente coordinate e computazionali riguardo il progetto dell'edificio e la sua costruzione. Da queste caratteristiche è possibile rilevare che la composizione degli edifici appartenenti al patrimonio storico monumentale e la modellazione parametrica BIM sono strettamente connessi, e pertanto il BIM ha le potenzialità per essere una eccellente metodologia operativa per la costruzione di un sistema architettonico basato sulla conoscenza [Apollonio et al. 20I3]. Le piattaforme BIM non sono soltanto degli ottimi strumenti di modellazione della geometria, ma consentono l'attribuzione di una serie di informazioni sui materiali, le tecniche, i periodi di realizzazione, tanto da poterle considerare un database generale per la comprensione e la documentazione del ciclo di vita dell'edificio. $\mathrm{Da}$ questo punto di vista il BIM è anche un prezioso strumento per facilitare gli studi teorici e storici sul manufatto, al fine di arricchirne la conoscenza. La geometria parametrica inoltre garantisce un elevato grado di flessibilità dei componenti e consente l'adattamento automatico degli elementi alle modifiche. Questa caratteristica è di fatto molto vicina al sistema della struttura semantica dell'architettura classica e delle sue proporzioni.

L'analogia tra la modellazione parametrica e la rappresentazione dell'architettura nella trattatistica si fa ancor più concreta se entrambe vengono a considerarsi come sistemi di conoscenza. In effetti, nella fase di modellazione soprattutto del costruito storico, l'operatore si pone gli stessi quesiti rappresentativi del trattatista rinascimentale, ovvero dover legare gli elementi tra loro cercando di individuarne rapporti proporzionali e logiche di ripetizione. Inoltre, la grande flessibilità che si riscontra nell'utilizzo di elementi architettonici canonici ripetuti ma con gradi di libertà per quanto riguarda i tipi, sembra essere perfettamente aderente alla modellazione per tipi delle famiglie parametriche.

Nello stesso concetto di 'parametrico', inoltre, si individuano affinità con la modularità dell'architettura storica; il termine parametrico fa riferimento alle relazioni esistenti tra tutti gli elementi del modello, che consentono il coordinamento e la gestione delle modifiche. In matematica e nei sistemi CAD di progettazione meccanica, i numeri o le caratteristiche che definiscono questo tipo di relazioni vengono definiti parametri, da cui l'uso di "parametrico" in riferimento all'operazione eseguita dal software. Nel concetto di ordine architettonico, è connaturato fin dall'antichità quello di serie, successione, ripetizione, nel senso di insieme, di strumenti atti a leggere un organismo architettonico come sistema numerico e armonico, riproponibile continuamente attraverso un modulo. Nel Libro III del De Architectura [I],Vitruvio si sofferma sulla necessità che la composizione del tempio sia basata su schemi proporzionali, cioè sulla commensurabilità di ogni singolo membro dell'opera e di tutti i membri nell'insieme dell'opera, per mezzo di una determinata unità di misura o commodulatio; questa per Vitruvio corrisponde al diametro della colonna misurato all'imoscapo [Bossalino 2002]. Ecco allora che il termine parametro e modulo, all'interno della modellazione trovano senso univoco nel definire gli oggetti della rappresentazione; le librerie di oggetti parametrici che si modellano per un manufatto storico in ambiente BIM si configurano dunque come le tavole dei Trattati in cui gli architetti e artisti dell'epoca rappresentavano le costruzioni geometriche degli elementi per poterli riproporre in cantiere (fig. I). 


\section{La modellazione dell'ordine}

Le facciate del Battistero di San Giovanni sono caratterizzate dal largo uso dell'ordine architettonico nelle sue diverse declinazioni: dallo ionico presente in rare semicolonne adiacenti le finestre del secondo registro, al corinzio, presente soprattutto nelle paraste del primo registro, al composito che caratterizza le colonne ai lati dei portali ma anche i pilastri ottagoni del secondo registro e le colonnette della lanterna. La varietà di configurazioni dell'ordine architettonico all'esterno di questo monumento storico è fra le principali ragioni di scelta della fabbrica medioevale come caso studio cui applicare la modellazione.

In primo luogo, si è proceduto con un'analisi geometrica e proporzionale dell'ordine, e si è definito un rapporto tra diametro della colonna e altezza complessiva della stessa (fig. 2). La definizione di tale rapporto è il primo di una serie di parametri da impostare all'interno della famiglia di modellazione parametrica dell'ordine. Si è scelto di utilizzare la tipologia di famiglia caricabile "pilastro architettonico metrico"; la scelta della famiglia caricabile consente di modellare l'elemento sempre all'interno del software BIM, ma in un file diverso da quello del browser di progetto. La famiglia caricabile, che nel caso dell'ordine architettonico diviene nidificata in quanto ospita al suo interno una serie di altre famiglie caricabili, consente di importare l'elemento modellato all'interno di distinti browser di progetto, andando così ad arricchire la libreria di oggetti parametrici a disposizione. Un ulteriore vantaggio, questa volta rispetto alla scelta specifica di pilastro architettonico metrico, sta nella possibilità che il pilastro architettonico ha di essere inglobato all'interno delle famiglie di sistema muro, del tutto o in parte, a differenza del pilastro strutturale metrico. Questa caratteristica si rende ottimale per la modellazione dell'ordine architettonico in facciata, spesso in forma di semicolonna o parasta, in parte accolta dalla superficie muraria. Questo tipo di famiglia possiede inoltre, un'altra importante caratteristica, ovvero quella di essere vincolata per sua natura al parametro di altezza, che viene espresso sotto forma di istanza. Ciò consente di replicare l'elemento pilastro più volte all'interno di uno stesso progetto, anche variando la sua altezza, che rimane un parametro legato allo specifico oggetto modellato; legando altri parametri di istanza a quest'ultimo, otterremo non solo il variare dell'altezza, ma il riproporzionamento di tutte le parti modellate in funzione di essa. II vantaggio della modellazione parametrica

Fig. I. Modellazione parametrica dell'ordine architettonico sulla base della trattatistic inascimentale: modellazione GDL in Grasshopper dell'ordine dorico [Murphy et. al. 2013], modellazione parametrica dell'ordine toscano del Vignola ed esploso assonometrico delle decorazioni di un capitello corinzio [Lo Turco, Novello 2016 In basso: modo 2016$]$ passo: parametrica della voluta Virno in Reg (2019) ignola in Revit (2019) cura dell'autrice.

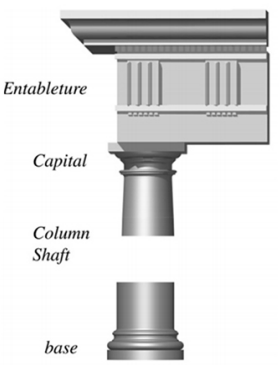

(a) 3D Model
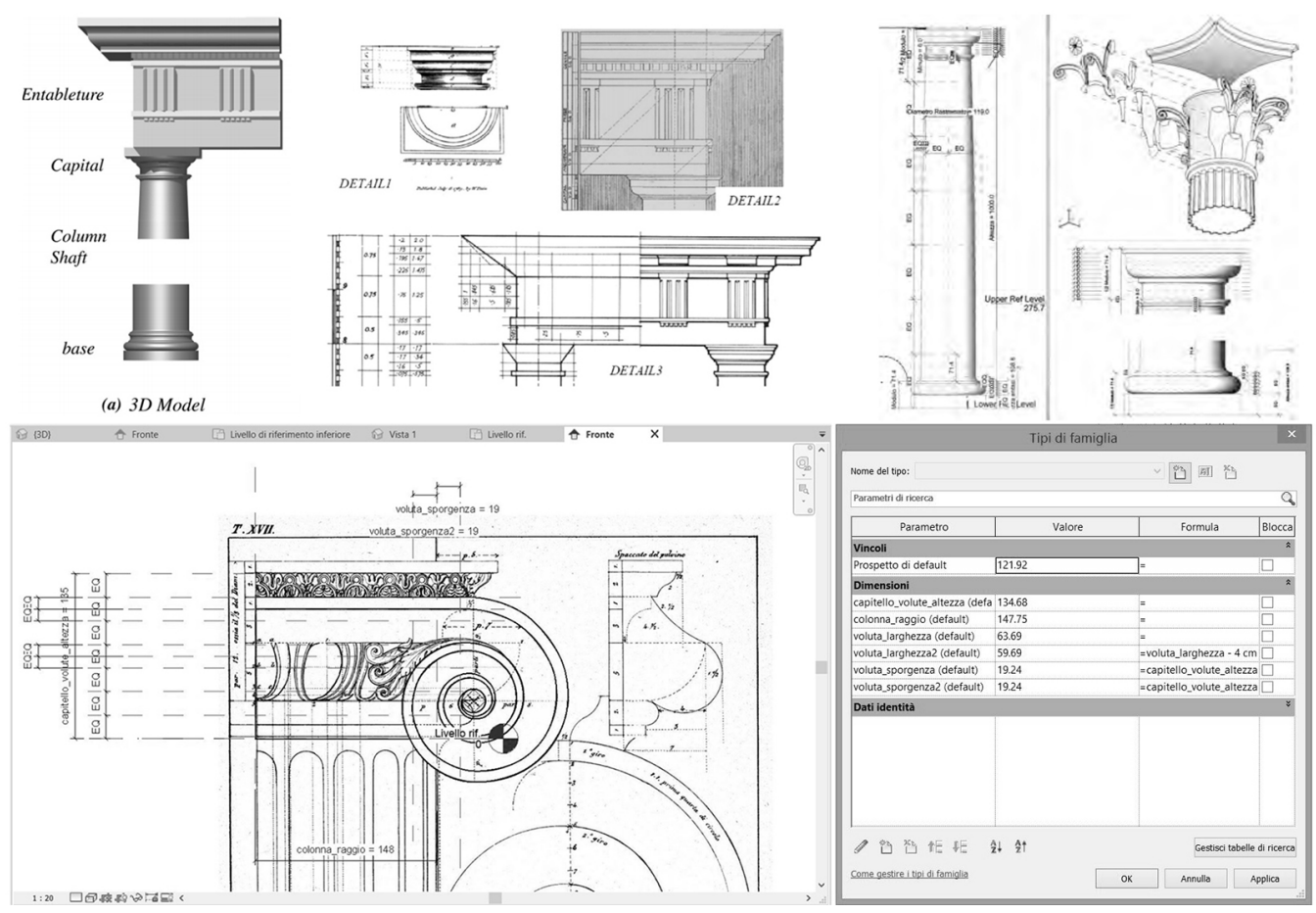
Fig. 2. Proporzionamento delle colonne composite ai lati della porta est. Si trovata corrispondenza nella divisione del diametro in 2 moduli che a loro volta sono tati distinti in 18 parti. Sulla base di questo proporzionamento sono tati impostati i paramet per la modellazione dell'ordine.
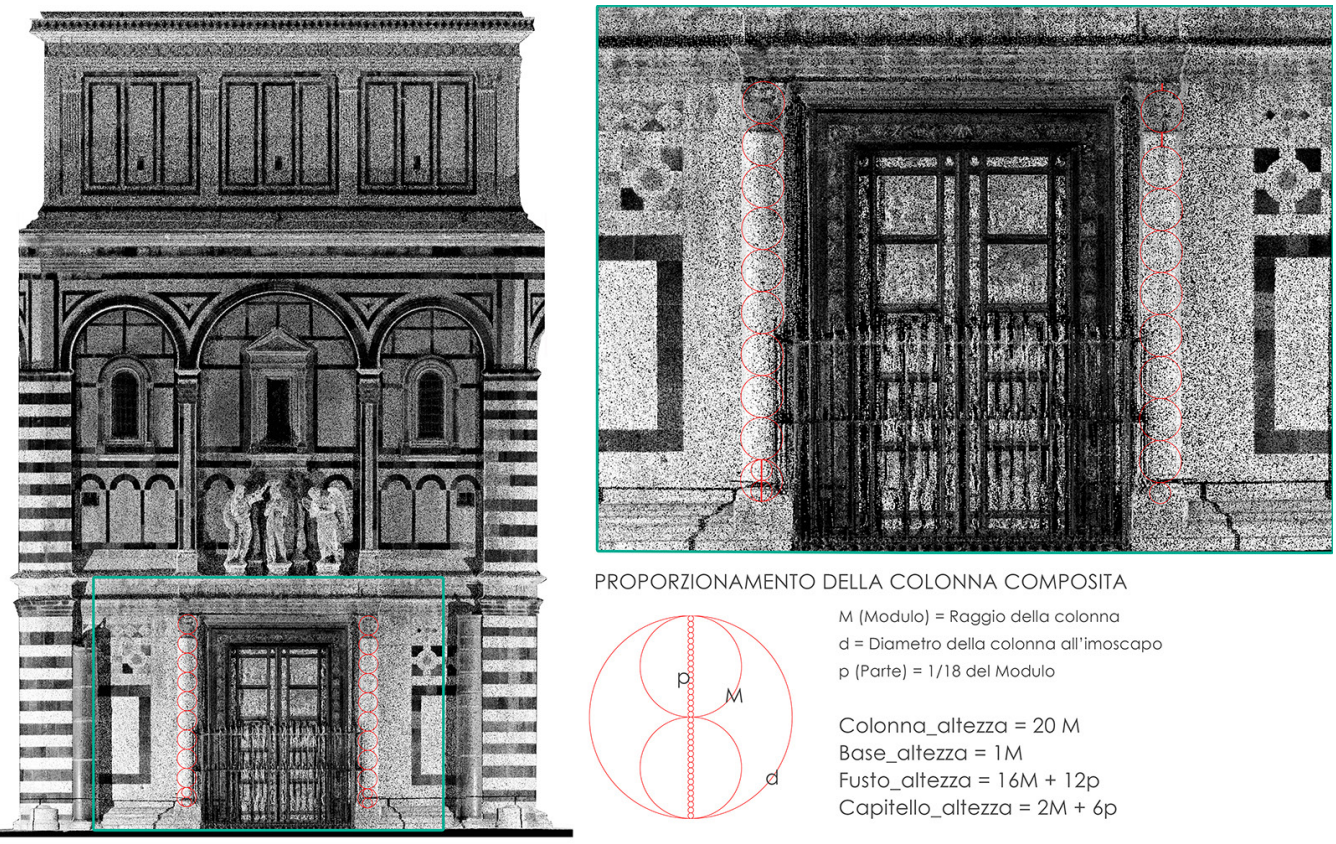

PROPORZIONAMENTO DELLA COLONNA COMPOSITA

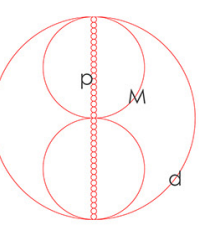

$M($ Modulo $)=$ Raggio della colonna

$\mathrm{d}=$ Diametro della colonna all' imoscapo

$p($ Parte $)=1 / 18$ del Modulo

Colonna_altezza $=20 \mathrm{M}$

Base_altezza $=1 \mathrm{M}$

Fusto_altezza $=16 \mathrm{M}+12 \mathrm{p}$

Capitello_altezza $=2 M+6 p$

risiede proprio nella possibilità che ogni oggetto, definito da diversi parametri possa essere replicato e modificato, consentendo il riadattarsi di tutti gli elementi che lo costituiscono, mantenendo gli stessi rapporti proporzionali. Nell'esempio mostrato in fig. 2 , si è proceduto con l'analisi proporzionale della colonna composita ai lati della porta est, detta del Paradiso.
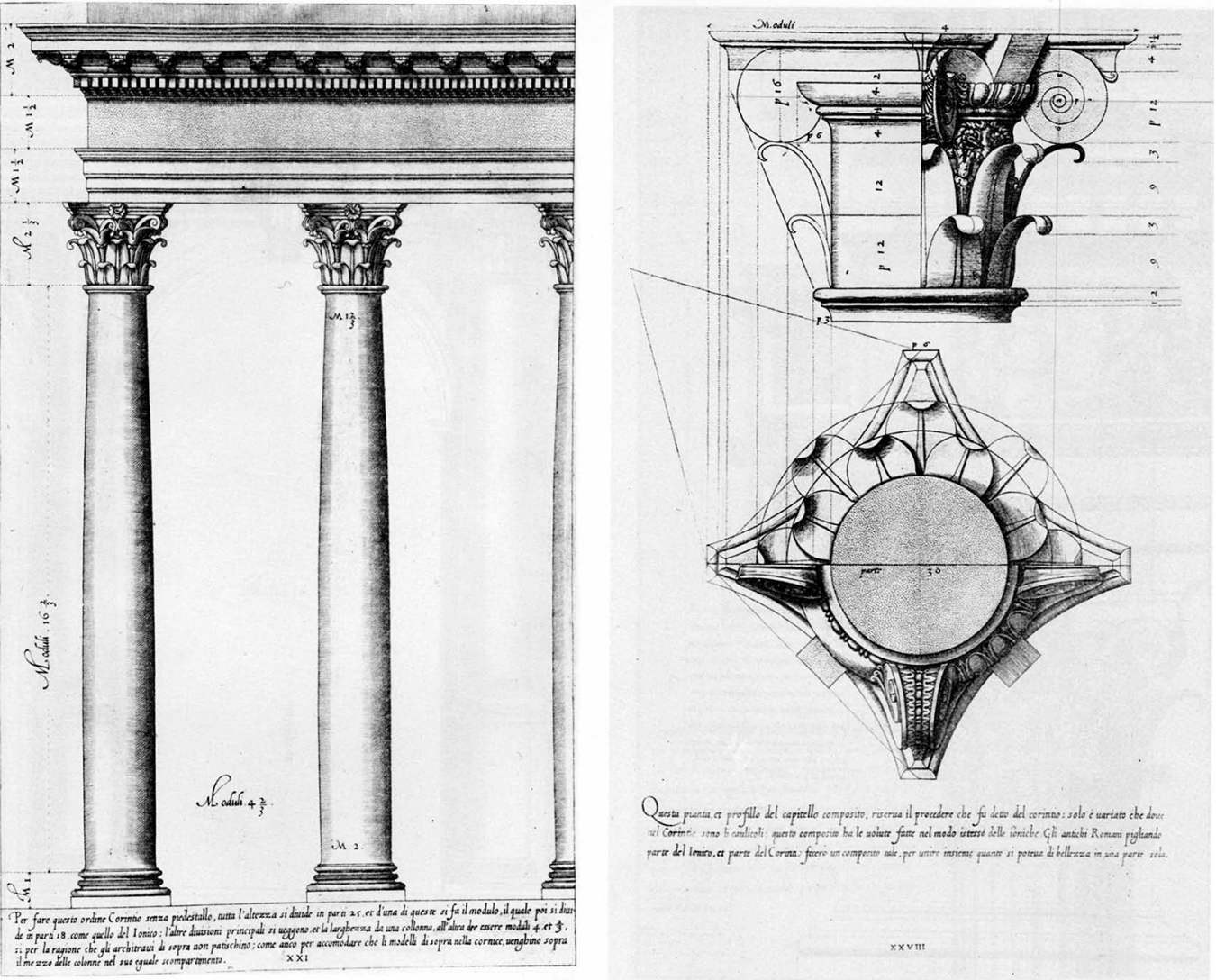
Misurato il diametro della colonna all'imoscapo, si è scelto di utilizzare come modulo il raggio della colonna e si è subito evidenziato come l'altezza della stessa fosse pari a 20 moduli (I 0 diametri) come definito dalla Regola del Vignola (Regola, tav. XXI e XXVIII) (fig. 3). stato dunque suddiviso il modulo il 18 parti, come per la Regola, ed è stato così possibile trovare riscontro nel proporzionamento anche delle parti più piccole, come il collarino e l'altezza dell'abaco. A questo punto l'analisi proporzionale è stata tradotta nell'impostazione dei parametri nella modellazione della colonna composita. In primis si è definito il parametro di 'colonna_raggio' uguale a I/20 dell'altezza della colonna; poi si è stabilito che l'altezza della base fosse pari alla colonna_raggio, il nostro modulo; in seguito, si è definito il parametro 'parte', come I//8 di colonna_raggio. Quest'ultimo parametro ha consentito la modellazione anche delle decorazioni a foglie d'acanto e degli elementi più piccoli, come collarino e abaco; l'altezza del solo fusto è pari alla formula $16 \times$ colonna_raggio $+12 \times$ parte, ovvero 16 moduli e 2/3.

Tutti i parametri inseriti a formare le formule generatrici della modellazione sono parametri di istanza, in quanto legati da un rapporto stretto con il parametro di istanza 'altezza' del pilastro metrico. Stesso discorso è stato fatto per tutte le colonne, paraste e pilastri presenti sulle facciate del monumento, andando a individuare i rapporti tra le parti per definire i parametri della costruzione (figg. 4, 5). Anche per le famiglie caricabili, come si fa solitamente all'interno di un nuovo progetto, è importante definire i piani di riferimento, ma soprattutto le annotazioni di quota tra questi, poiché consentono di legare le distanze ai parametri inseriti, e inoltre fungono da riferimento per alloggiare altre famiglie caricabili come, ad esempio, i modelli generici metrici. Le famiglie caricabili "modello generico metrico" consentono la modellazione di oggetti metrici caricabili sia all'interno del progetto che all'interno di altre famiglie caricabili. Nello specifico, sono stati utilizzati per la modellazione parametrica delle volute, sia ioniche che composite, ma anche per altri elementi decorativi dei capitelli. La base attica invece, per

Fig. 4. Modellazione degli elementi di sostegno verticali: modellazione e impostazione dei parametri della colonna composita del portale, e della colonnapilastro ottagonale del secondo registro con capitello composito. L'impostazione dei parametri istanza parametri istanza sempre di preventivo proporziona prevtivo proporzionamento de elementi modulari.

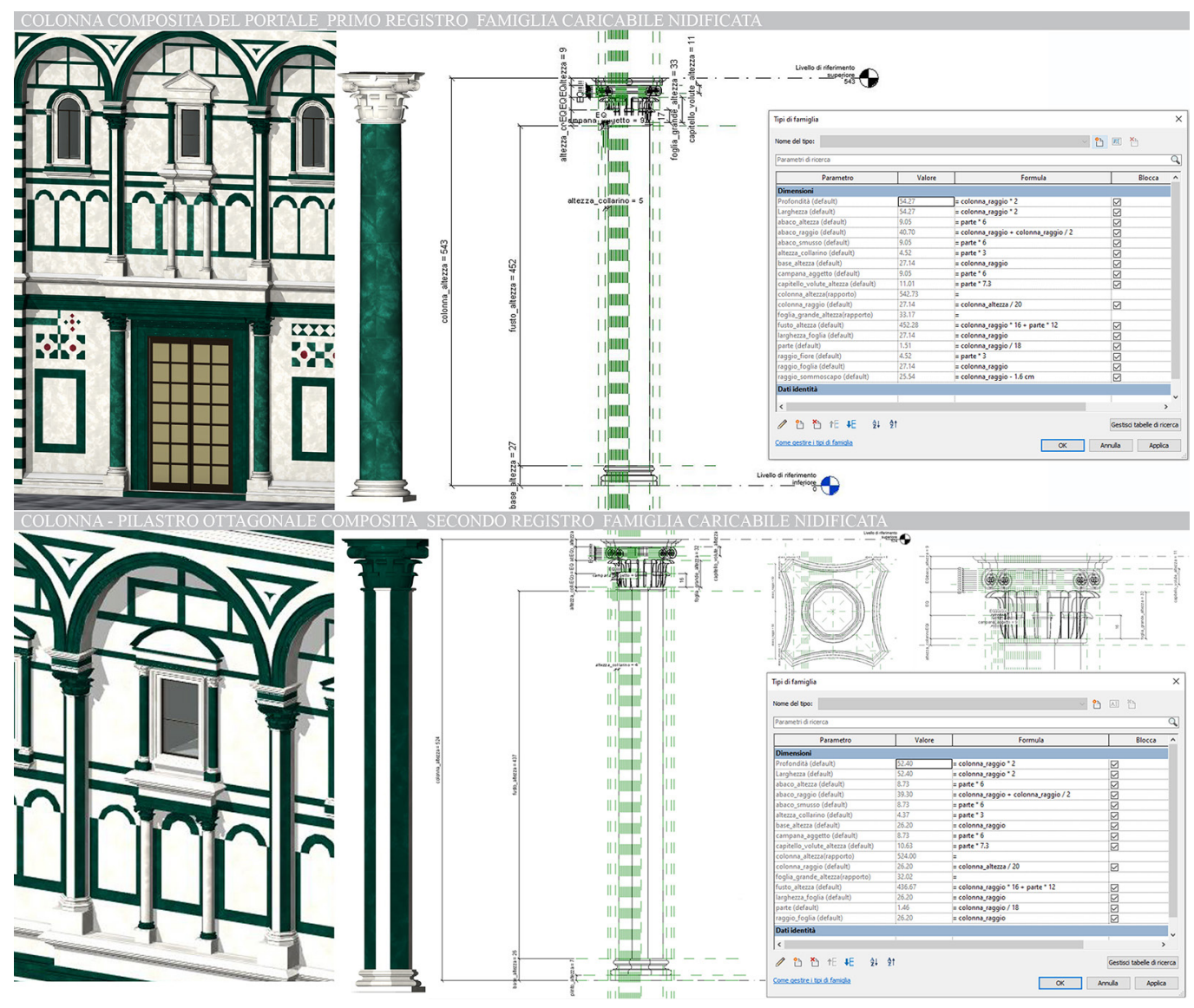




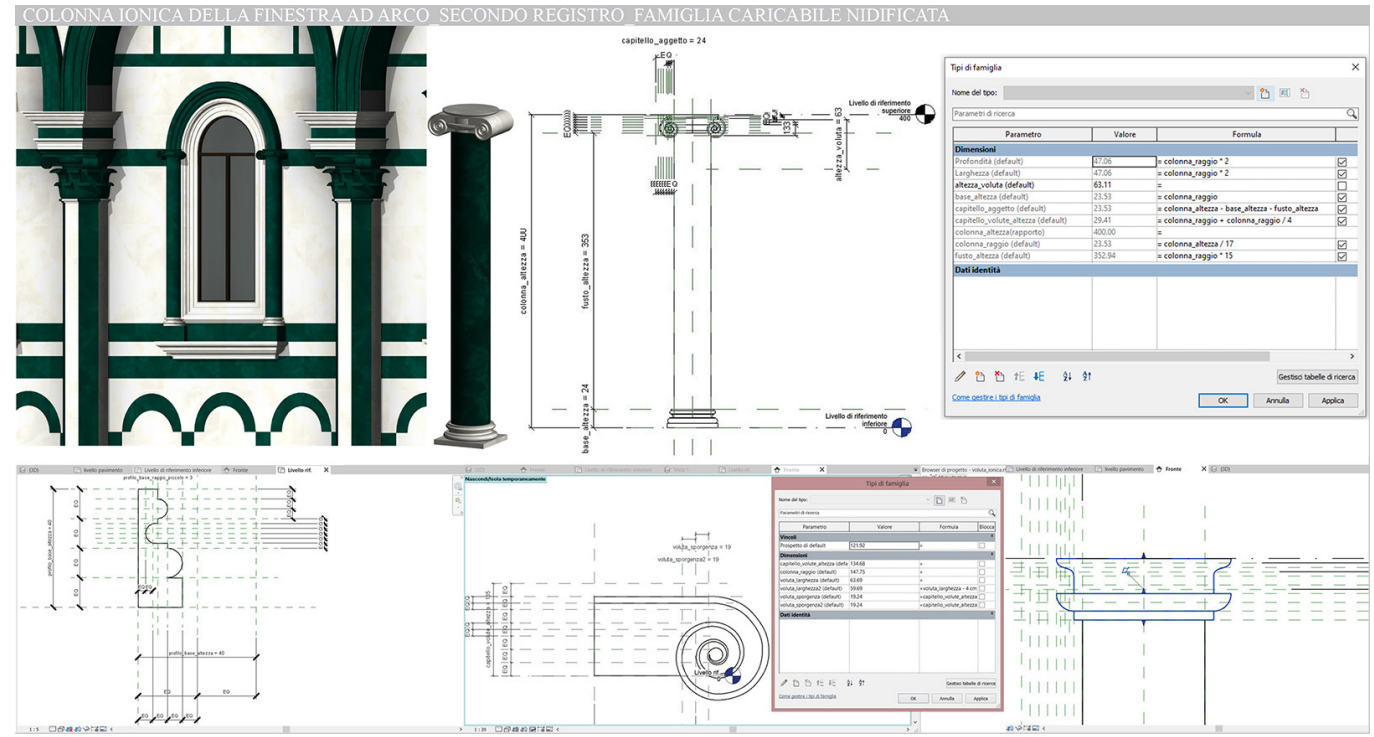

tutte le tipologie di colonna o pilastro è stata modellata prima come famiglia di profilo metrico e poi estrusa all'interno della famiglia caricabile di riferimento. Tanto nelle famiglie di profilo metrico, quanto nei modelli generici metrici che si vogliono caricare all'interno di famiglie, occorre modellare con i parametri di tipo, in quanto, in fase di importazione nella famiglia, occorre legarli e vincolarli ad altri parametri di istanza già presenti. Particolare attenzione andrà posta all'uniformare le unità di misura impiegate, tanto nel progetto quanto nelle famiglie caricabili. Nella modellazione del profilo metrico della base attica, il parametro di tipo che è stato agganciato alla famiglia colonna è l'altezza della base, che nella famiglia caricabile è un parametro di istanza legato al raggio della colonna (fig. 6). Allo stesso modo, nel modello generico della voluta, il parametro dell'altezza della voluta viene legato allo stesso parametro di istanza nella famiglia caricabile. Quando si modella un elemento metrico è sempre opportuno specificare che questo sia basato su piano di lavoro, in quanto facilita l'inserimento nella famiglia caricabile dell'oggetto al relativo piano di rifermento. Procedura analoga è stata utilizzata per la modellazione dell'abaco dei capitelli compositi, corinzi e ionici, con l'unica eccezione del profilo da estrudere, che è stato modellato direttamente allinterno della specifica famiglia utilizzando il comando di estrusione o di rivoluzione. Stesso discorso per la modellazione delle parti decorative del capitello come le foglie d'acanto, che sono state modellate direttamente all'interno della famiglia specifica come estrusione, in quanto legate alla singola configurazione.

Fig. 6. Modellazione della base attica e della voluta e successiva associazione dei loro parametri a quelli presenti nella famiglia colonna pilastro. L'associazione dei parametri consente la modifica dimension la modica dimensionale l'allo colonna garantendo l'adattamento anche

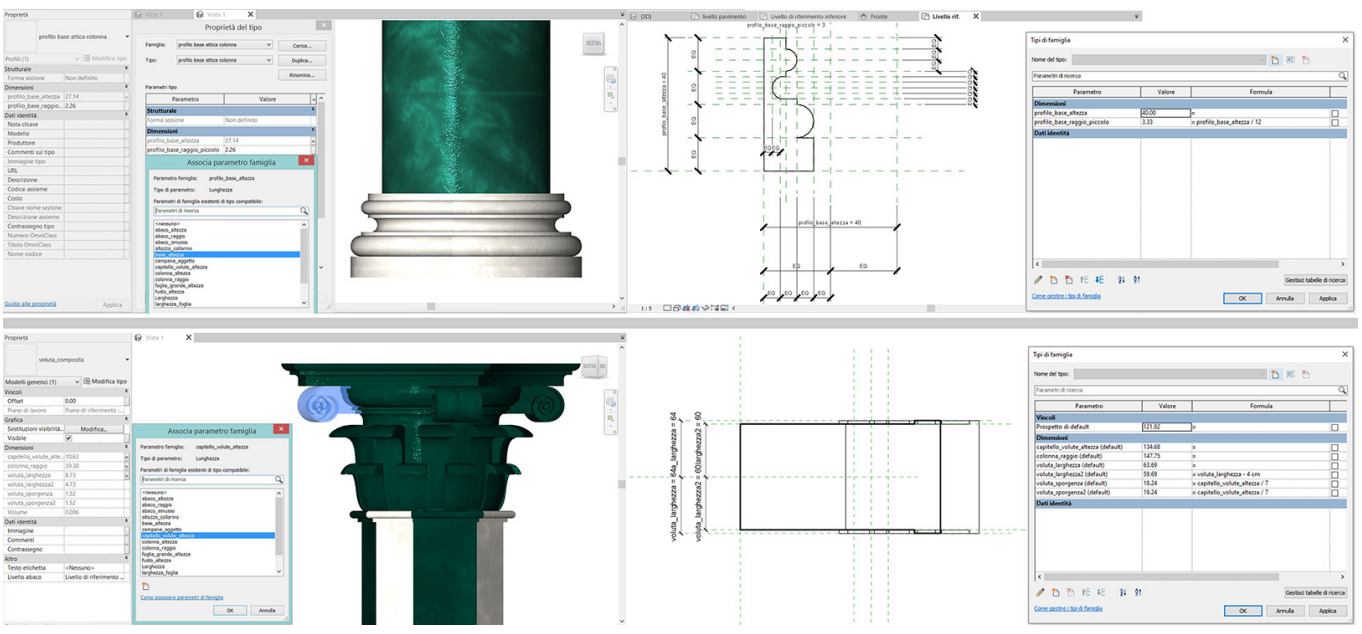


Fig. 7. Modellazione dell'entasi della colonna secondo il procedimento illustrato da Palladio. A sinistra: illustrazione grafica del procedimento disegnata da Riccardo Migliari [Migliari 1991, p. 56]
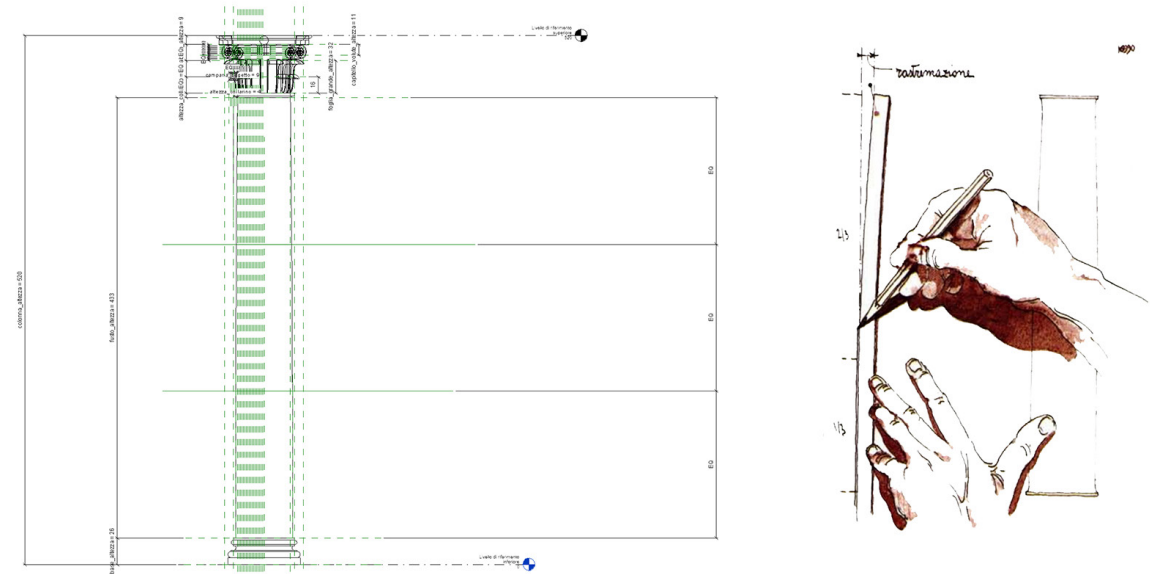

\section{La rastremazione del fusto o èntasis}

II fusto della colonna nell'ordine architettonico, subisce generalmente una rastremazione, ovvero un restringimento graduale a partire da circa I/3 dell'altezza, fino a misurare al sommoscapo

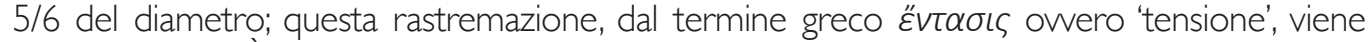
definita èntasis. È un accorgimento ottico che mette in evidenza la robustezza della membratura rappresentando lo stato di tensione della colonna che reagisce alla compressione a cui è sottoposta. Molti trattatisti rinascimentali descrivono il procedimento geometrico per la rappresentazione geometrica dell'èntasi, da quello più intuitivo del Palladio, che affonda le sue radici nella pratica di cantiere [Migliari 199I, p. 56], a quello geometrico di Vignola e Chitham. Per la modellazione parametrica della rastremazione delle colonne composite del portale è stato applicato il metodo di Palladio, piuttosto pratico e che ben si adatta alla logica parametrica. "Partisco il fusto della colonna in tre parti eguali, e lascio la terza parte da basso dritta a piombo, a canto l'estremità della quale pongo in taglio una riga sottile alquanto lunga come la colonna o poco più, e muovo quella parte che avanza dal terzo in suso e la storco finché 'I capo suo giunga al punto della diminuzione di sopra della colonna sotto il collarino; e secondo quella curvatura segno, e così mi viene la colonna alquanto gonfia nel mezo, e si rastrema molto garbatamente" [Migliari 1991, p. 56].

Allo stesso modo si è suddiviso il fusto della colonna in tre parti uguali con l'ausilio dei piani di riferimento e delle solite annotazioni e si è generata una estrusione per rivoluzione del fusto. In questo caso il software ci chiede di determinare le linee di contorno, ovvero il profilo che deve essere estruso, e la linea d'asse, ovvero l'asse di rivoluzione. Conoscendo il diametro della colonna all'imoscapo e al sommo scapo, viene definita una linea di contorno ancorata ai piani di riferimento inferiore e superiore del fusto, e una linea retta per il primo terzo del profilo della colonna; a questo viene poi vincolato un arco tangente che consente di rappresentare la rastremazione. II profilo così formato viene estruso per rivoluzione l'ungo asse di simmetria della colonna. Avendo vincolato i piani inferiore e superiore del fusto, relazionati ai parametri del raggio della colonna in quel punto, modificando l'altezza della colonna l'entasi si adatta perfettamente (fig. 7). Questa operazione consente di modellare l'entasi del fusto della colonna attraverso un'operazione di fitting perfetto con la nuvola di punti. Un'ulteriore procedura può essere quella di seguire la costruzione geometrica proposta da Vignola e Chitham. Nello specifico, il metodo prevede che l'altezza della colonna, fissato il diametro, sia divisa in tre parti uguali, e che l'entasi riguardi i 2/3 di questa, mentre il primo terzo rimanga cilindrico. All'altezza del primo terzo del fusto si descrive una semicirconferenza; si dividono poi i $2 / 3$ superiori del fusto in un numero scelto di parti uguali, si stabilisce il diametro al sommoscapo e si proiettano assi paralleli dagli estremi del diametro fino a incontrare la semicirconferenza alla base dell'entasi. Si stacca pertanto sulla semicirconferenza un arco, che verrà diviso per lo stesso numero di parti uguali con cui si sono suddivisi i 2/3 del fusto. Da queste parti si prolungano rette parallele all'asse che, all'incontro con le corrispondenti perpendicolari individuano i punti per i quali passa la curva di rastre- 
Fig. 8. Modellazione dell'entasi della colonna secondo il procedimento illustrato da Vignola e Chitham.
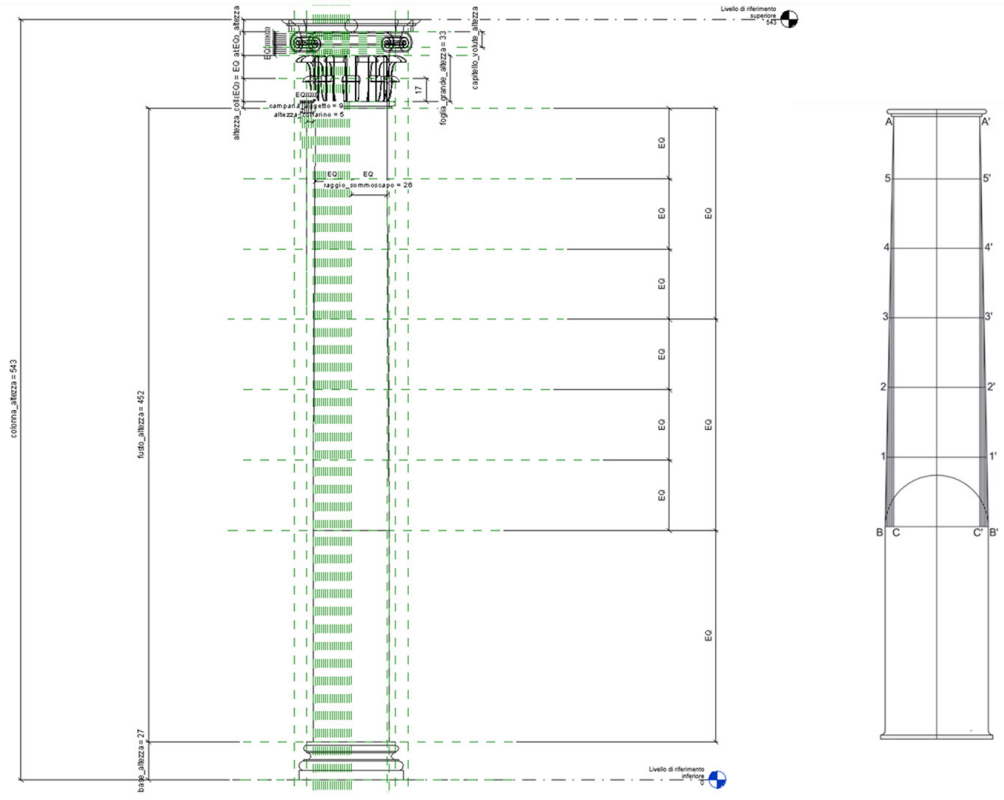

mazione (fig. 8). Si noti che, nonostante Vignola e altri propongano una costruzione della rastremazione differente per le colonne corinzie o composite, in questo caso si è riscontrata, nelle colonne del Battistero, la rastremazione adottata per le colonne toscane o composite, che prevede la rastremazione solo verso il sommoscapo. A questo punto si presentano due strade per realizzare la rastremazione dei $2 / 3$ del fusto: in un primo caso è possibile unire i punti per cui passa la curva con una spline, oppure assimilare la curva descritta a un arco ellittico che è possibile modellare all'interno della piattaforma BIM. Nel primo caso occorre sapere che utilizzando la spline, i punti di controllo consentono di approssimare bene una curva passante per i sei punti; inoltre, la sciando gli estremi della curva liberi da vincoli, essa si adatta perfettamente alle modifiche in altezza della colonna. Nel secondo caso occorre invece fare riferimento alla costruzione matematica e geometrica dell'ellisse come descritto da Paul Aubin [Aubin 2019] [2]: per costruire un'ellisse nel piano cartesiano abbiamo bisogno di riferirci all'equazione canonica, ovvero $x^{\wedge} 2 / b^{\wedge} 2+y^{\wedge} 2 / a^{\wedge} 2=1$.

Nel nostro caso, abbiamo tre dei valori richiesti per risolvere la formula: la somma delle sei parti uguali sono l'altezza dell'entasi che nella formula standard rappresenta y; il raggio della colonna all'imoscapo equivale all'asse minore dell'ellisse b; il raggio della colonna al sommoscapo equivale alla $x$. Pertanto, la nostra equazione diventa $a=\sqrt{y^{\wedge}} 2 /\left(1-x^{\wedge} 2 / b^{\wedge} 2\right)$, in cui a è il semi asse maggiore dell'ellisse. Codificando questa formula in un linguaggio comprensibile al software, imponiamo che il parametro semi asse maggiore debba seguire la formula: sqr$\mathrm{t}(($ entasi^2) / ( I-(raggio_sommoscapo^2) / (colonna_raggio^2)) [3].

È possibile quindi estrudere il profilo di arco ellittico per $\mathrm{i} 2 / 3$ del fusto e un cilindro per il primo terzo. In questo modo l'entasi della colonna diviene parametrica a tutti gli effetti poiché legata a parametri di istanza già espressi nella famiglia (fig. 9).

\section{Conclusioni}

Se pensiamo alla procedura vitruviana di rappresentazione dell'ordine architettonico per partizioni successive, sapientemente illustrata da Migliari [Migliari 199/], essa viene distinta in tre livelli principali, intimamente riferiti alla triade vitruviana di firmitas, utilitas e venustas; questi livelli sono il Livello Costruttivo, quello delle grandi masse e del primo proporzionamento, il Livello Funzionale, che comprende invece le parti più piccole, generate per divisione degli altri elementi, e infine il Livello Decorativo, in cui ogni elemento viene completamente modellato per mezzo della giustapposizione e del proporzionamento delle modanature. È qui che ogni ordine 
Fig. 9. Modellazione dell'entasi della colonna secondo il procedimento dell'arco ellittico parametrico.

Fig. I0. I tre livelli di scomposizione dell'ordine architettonico come concepiti da Riccardo Migliari nell'articolo II disegno degli ordini e il rilievo dell'architettura classica: Cinque Pezzi Facil del 1991. Rielaborazione grafica a cura dell'autrice.

Fig. II. Scomposizione delle parti architettoniche di un podio secondo la classificazione vitruviana interpretata da Migliari.
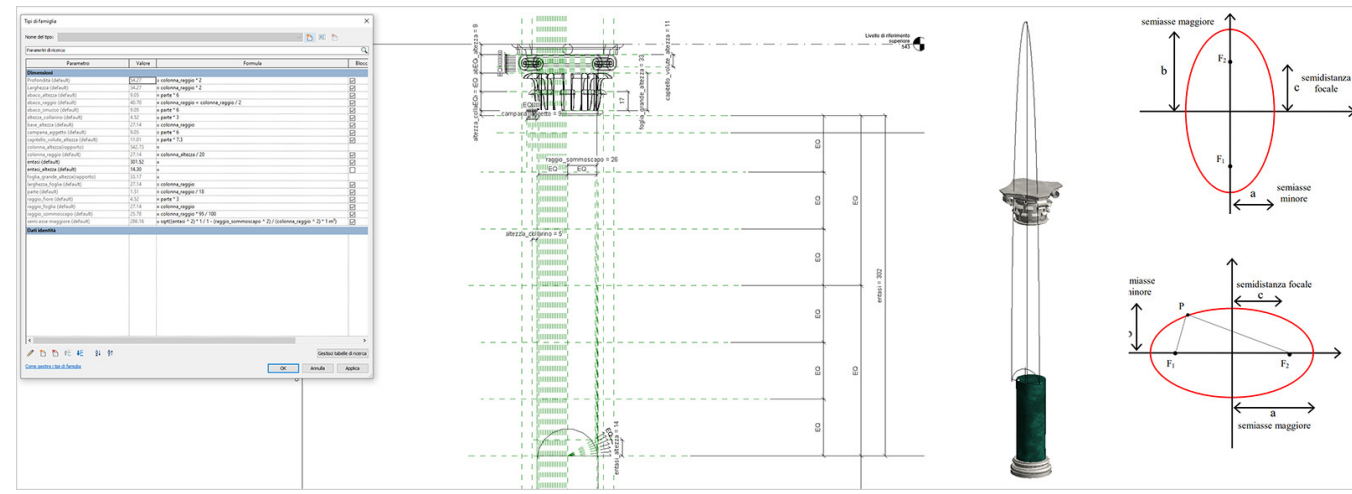

si caratterizza (fig. 10). In effetti, anche per la modellazione parametrica degli elementi questa scomposizione a tre livelli sembra essere coerente [Potestà, Bianchini 2020]. In questo caso, come descrive Migliari, si avrebbe un livello di dettaglio basso, costruttivo, in cui compaiono solo le grandi masse, le parti strutturali ed essenziali, un livello successivo in cui vengono rappresentate tutte le parti funzionali dell'elemento architettonico, un terzo e ultimo livello in cui vengono a delinearsi anche le decorazioni, e l'elemento assume il suo aspetto completo (fig. I I). Ricapitolando i passaggi utili e necessari alla modellazione dell'ordine architettonico in forma parametrica, ci si accorge che alla base vi è senza dubbio l'analisi geometrico proporzionale dell'elemento architettonico analizzato. Nell'impostazione dei parametri c'è fin da subito la con-
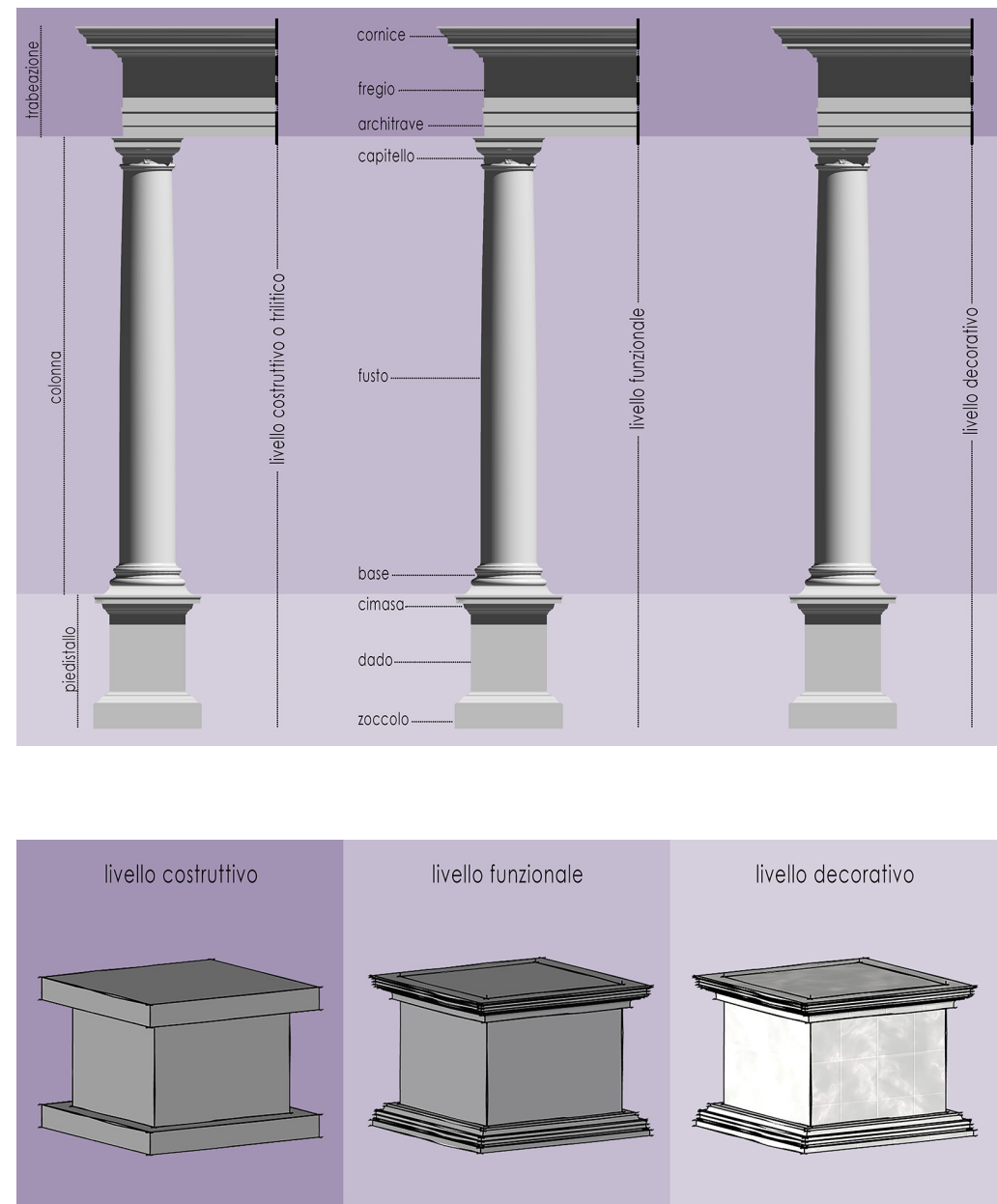
sapevolezza che ogni elemento debba essere legato agli altri da rapporti reciproci e vincoli, che la modifica apportata a un elemento faccia immediatamente modificare il tutto in termini proporzionali, e che il tutto è governato dallo stretto rapporto tra diametro (o larghezza) e altezza. Il concetto di modulo, come già si è detto e strettamente legato al moderno concetto di parametro; si tratta di individuare la regola sottesa al tutto.

Lo sforzo richiesto all'operatore che modella l'ordine, o più in generale l'architettura storica, è proprio quello di leggere nell'architettura i rapporti proporzionali usati e individuarne le logiche e le gerarchie proporzionali in modo da poterlo rappresentare nella maniera corretta. Stesso sforzo tentavano di compiere i trattatisti rinascimentali, convinti di poter rappresentare l'ordine architettonico seconda una 'regola'.

\section{Note}

[I] || De Architectura libri decem (I dieci libri dell'architettura) è il più antico trattato di architettura, e l'unico datato prima della nascita di Cristo che sia pervenuto nella sua interezza. Oltre a fornirci preziose informazioni sulle opere e sui principi architettonici dell'antichità, esso è anche il testo di riferimento di tutte le teorie architettoniche a partire dal Rinascimento. Scritto probabilmente nel secondo o terzo decennio a. C., il trattato è dedicato all'imperatore Augusto, ed è opera di un ingegnere militare dell'armata romana conosciuto come Gentile Vitruvio. Durante il medioevo il testo viene tramandato in numerosi manoscritti, tuttavia perdendo il suo ruolo principale nella pratica costruttiva; è solo nel XV secolo con Leon Battista Alberti che viene riconosciuto in esso un modello esemplare e diviene testo di riferimento. Diviene cosi uno dei trattati più importanti dell'epoca moderna e tra il XV e XVI secolo vengono realizzate numerose edizioni illustrate, a cura di grandi personaggi come Serlio, Palladio, Vignola, che rendono la teoria di Vitruvio divulgabile e applicabile.

[2] Questa procedura è stata adottata da Paul Aubin nella modellazione del fusto della colonna e descritta nel volume Renaissance Revit utilizzando il metodo descritto da Chitham.

[3] Qualora il software riscontrasse l'errore 'unità di misura disomogenee' occorre moltiplicare o divide per I.

\section{Riferimenti bibliografici}

AA.W. (20I I). Teoria dell'architettura: 89 trattati dal Rinascimento ad oggi.Voll. II. Köln:Taschen Biblioteca Universalis.

Apollonio F. I., Gaiani M., Sun Z. (20I3). 3D modeling and data enrichment in digital reconstruction of architectural heritage. In The International Archives of the Photogrammetry, Remote Sensing and Spatial Information Sciences, XXIV International CIPA Symposium. Strasbourg 2-6 September 2013, volume XL-5/W2, pp. 43-48.

Aubin F.P. (2013). Reinassance Revit. Creating classical architecture with modern software. Oak Lawn: G3B Press.

Bossalino F. (2002). De Architettura libri X. Bologna: Kappa Edizioni.

Cassa di Risparmio di Vignola (a cura di) (1974). Regola delli cinque ordini d'architettura di M. lacomo Barozzio da Vignola. Bologna: Arti Grafiche Tamari.

Migliari R. ( |99| ). II disegno degli ordini e il rilievo dell'architettura classica: Cinque Pezzi Facili. In Disegnare Idee Immagini, anno II, vol. 2, pp. 49-66. Roma: Gangemi Editore.

Murphy M., MC Govern E., Pavia S. (2013). Historic Building Information Modelling - Adding intelligence to laser and image-based surveys of European classical architecture. In ISPRS Journal of Photogrammetry and Remote Sensing, 76, pp. 89- I 02.

Novello G., Lo Turco M. (20 16). La tridimensionalità dell'Architettura e la sua Rappresentazione: un ponte sospeso tra le interpretazioni dei trattatisti italiani del XVI secolo e le metodologie di elaborazione della contemporaneità. In Ega el arquitecto, de la tradición al siglo XXI,Tomo I, pp. I24I-1250.

Paolucci A. (1994). Il battistero di San Giovanni a Firenze. Modena: Cosimo Panini Editore.

Potestà G., Bianchini C. (2020). BIM for built cultural heritage: semantic segmentation, architectural stratification and LOD of the Baptistery of San Giovanni in Florence. In Bolognesi C., Villa D. (a cura di). From Building Information Modelling to Mixed Reality, Springer Tracts in Civil Engineering, pp. I - 15. Cham: Springer.

\section{Autore}

Giorgia Potestà, Sapienza Università di Roma, giorgia.potesta@uniromal.it

Per citare questo capitolo: Potestà Giorgia (2021). Modellazione BIM parametrica eTrattati: analogie nella rappresentazione dell'ordine architettonico/Parametric BIM Modeling and Treatises: Analogies in the Representation of the Architectural Order. In Arena A., Arena M. Mediati D. Raffa P. (a cura di) Connettere Un diseono per annodare e tessere Linguagoi Distanze Tecnologie Atti del $42^{\circ}$ Convegno Internazionale dei Docenti delle Discipline della Rappresentazione/Connecting. Drawing for weaving relationship. Languages Distances Technologies. Proceedings of the 42th International Conference of Representation Disciplines Teachers. Milano: FrancoAngeli, pp. 2587-2606. 


\title{
Parametric BIM Modeling and Treatises: Analogies in the Representation of the Architectural Order
}

\author{
Giorgia Potestà
}

\section{Abstract}

The research reflects on the possibility of parametric BIM modeling of the architectural order starting from the proportional geometric analysis of historical architecture. The study of the Renaissance treatises, but above all the tables depicting the representations of the architectural order, provide ideas for the choice and setting of the parameters for modeling. Starting point, as for all activities involving the knowledge of historical architectural artifacts, are the massive data acquisitions, in this case from TLS, to support the parametric restitution of the architectural order through modeling for nested families. Affinity between the concept of module and parameter in scientific terms emerge clearly and constitute the indissoluble bond for the knowledge and design of historical built architecture.

Parole chiave

parametric modeling, HBIM, architectural order, treatises.

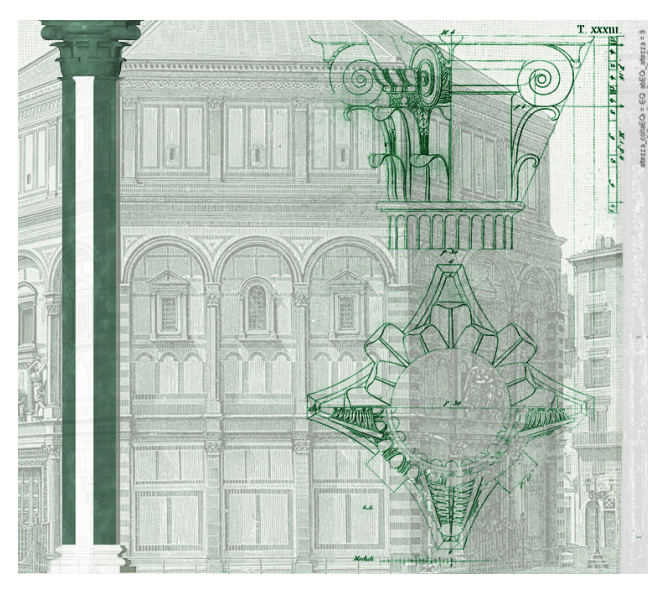

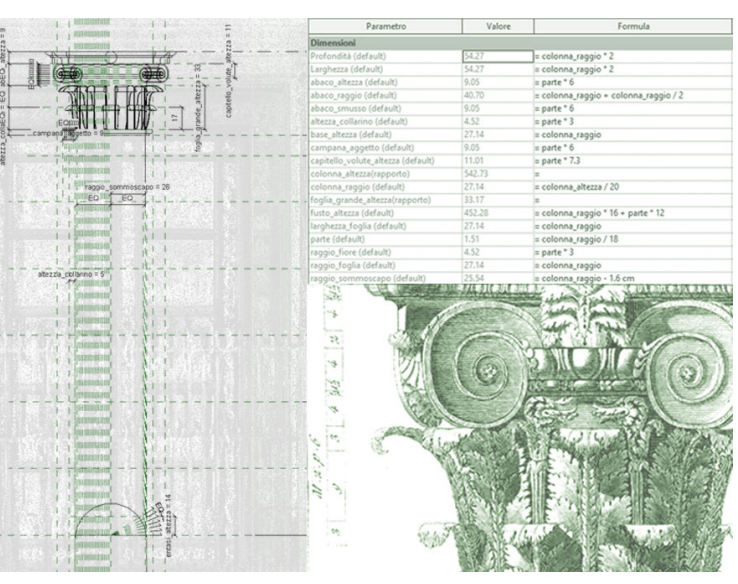




\section{Introduction}

"Rather, it is good to specify what is meant here by 'drawing' of the classical order. (...) but we also mean the interpretation of this rule, i.e. the reading of the dependence of each party on the other and the measurement of the dimensional relationships between the various parts; finally, we mean the outline of a general rule that is not a rule, but rather a plot on which to set the drawing, understood as it has been said. (...) The idea of a design of the order in which it is mental and graphic operations, their progress and their interdependencies, that defines the result seems seductive to me, also because it allows to overcome, definitively, 'the embarrassment of the rule': which, in fact, the rule and which the treatise to consider, to deal with the study of the order, since all the rules are different?" [Migliari R. 1991, p. 49].

In fact, Building Information Modeling is a methodology, or rather a process of design and documentation of buildings, characterized using internally coordinated and computational information about the design of the building and its construction. From these characteristics it can be noted that the composition of buildings belonging to the monumental historical heritage and the BIM parametric modeling are closely connected, and therefore BIM has the potential to be an excellent operational methodology for the construction of an architectural system based on knowledge [Apollonio et al 20 I3]. BIM platforms are not only excellent tools for modeling geometry but allow the attribution of a series of information on materials, techniques, periods of realization, to consider them a general database for understanding and documentation of the life cycle of the building. From this point of view BIM is also a valuable tool to facilitate theoretical and historical studies on the artifact, to enrich its knowledge. Parametric geometry also provides a high degree of flexibility of components and allows the elements to be automatically adapted to changes. This feature is in fact very close to the system of the semantic structure of classical architecture and its proportions.

The analogy between parametric modeling and the representation of architecture in the treatise becomes even more concrete if both come to be considered as systems of knowledge. In fact, in the modeling phase especially of the historical construction, the operator asks the same representative questions as the Renaissance treatise, that is, having to tie the elements together trying to identify proportional and logical repetition ratios. In addition, the great flexibility found in the use of canonical architectural elements repeated but with degrees of freedom with regard to types, seems to be perfectly adherent to modeling by types of parametric families.

Furthermore, the same concept of 'parametric' identifies affinities with the modularity of historical architecture; the term parametric refers to the relationships between all elements of the model, which allow for coordination and change management. In mathematics and mechanical design CAD systems, the numbers or characteristics that define this type of relationship are defined as parameters, hence the use of 'parametric' about the operation performed by the software. In the concept of architectural order, the concept of series, succession, repetition, in the sense of a whole, of tools designed to read an architectural organism as a numerical and harmonic system, which can be repeated continuously through a module, has been inherent since ancient times. In Book III of De Architectura [I], Vitruvius focuses on the need for the composition of the temple to be based on proportional schemes, that is, on the commensurability of each individual member of the work and of all the members in the work as a whole, by means of a certain unit of measurement or commodulatio; this for Vitruvius corresponds to the diameter of the column measured at the imoscapo [Bossalino 2002]. So, the terms parameter and module, within the modeling, find a unique meaning in defining the objects of the representation; the libraries of parametric objects that are modeled for a historical artifact in a BIM environment are therefore configured as the tables of the Treaties in which the architects and artists of the time represented the geometric constructions of the elements to be able to reproduce them on site (fig. I). 


\section{Order modeling}

The façades of the Baptistery of San Giovanni are characterized by the wide use of the architectural order in its various declinations: the lonic order is present in the semi-columns on the sides of the windows, the Corinthian is present in the pilasters of the first register, the composite characterizes the columns at the sides of the portals but also the octagonal pillars of the second register and the columns of the lantern. The variety of configurations of the architectural order outside this historic monument is one of the main reasons for choosing the medieval building as a case study to apply modeling to.

First, we proceeded with a geometric and proportional analysis of the order, and a ratio was defined between the diameter of the column and its overall height (fig. 2). The definition of this relationship is the first of a series of parameters to be set within the order parametric modeling family. We have chosen to use the "metric architectural pillar" type of loadable family; the choice of the loadable family allows you to model the element always within the BIM software, but in a different file. The loadable family, which in the case of the architectural order becomes nested, as it hosts a series of other loadable families within it, allows you to import the modeled element into separate project browsers, thus enriching the library of objects parametric available. A further advantage, this time with respect to the specific choice of metric architectural pillar, lies in the possibility that the architectural pillar has to be incorporated within the wall system families, in whole or in part, unlike the metric structural pillar. This feature is optimal for modeling the architectural order on the facade, often in the form of a semi-column or pilaster, partly received by the wall surface. This type of family also has another important feature, namely that of being bound by its nature to the height parameter, which is expressed in the form of an instance. This allows you to replicate the pillar element several times within the same project, even by varying its height, which remains a parameter linked to the specific modelled object; by linking other instance parameters to the latter, we will obtain not only the variation of the height, but the re-proportioning of all the parts modelled as a function of it. The advantage of parametric modelling lies precisely in the possibility that each object, defined by different parameters, can be replicated and modified, allowing the readjust-

Fig. I. Parametric modeling of the architectural order based on Renaissance treatises: GDL modeling in Grasshopper of the Doric order [Murphy et. Al. 20 I3], parametric modeling of the Tuscan order by Vignola and axonometric exploded view of the decorations of a Corinthian capital [Lo Turco, Novello 2016]. Below: parametric modeling of the lonic modeling of the lonic volute on the Vignola
Rule in Revit 2019 by the author.

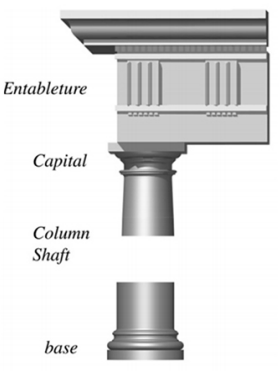

(a) $3 D$ Model
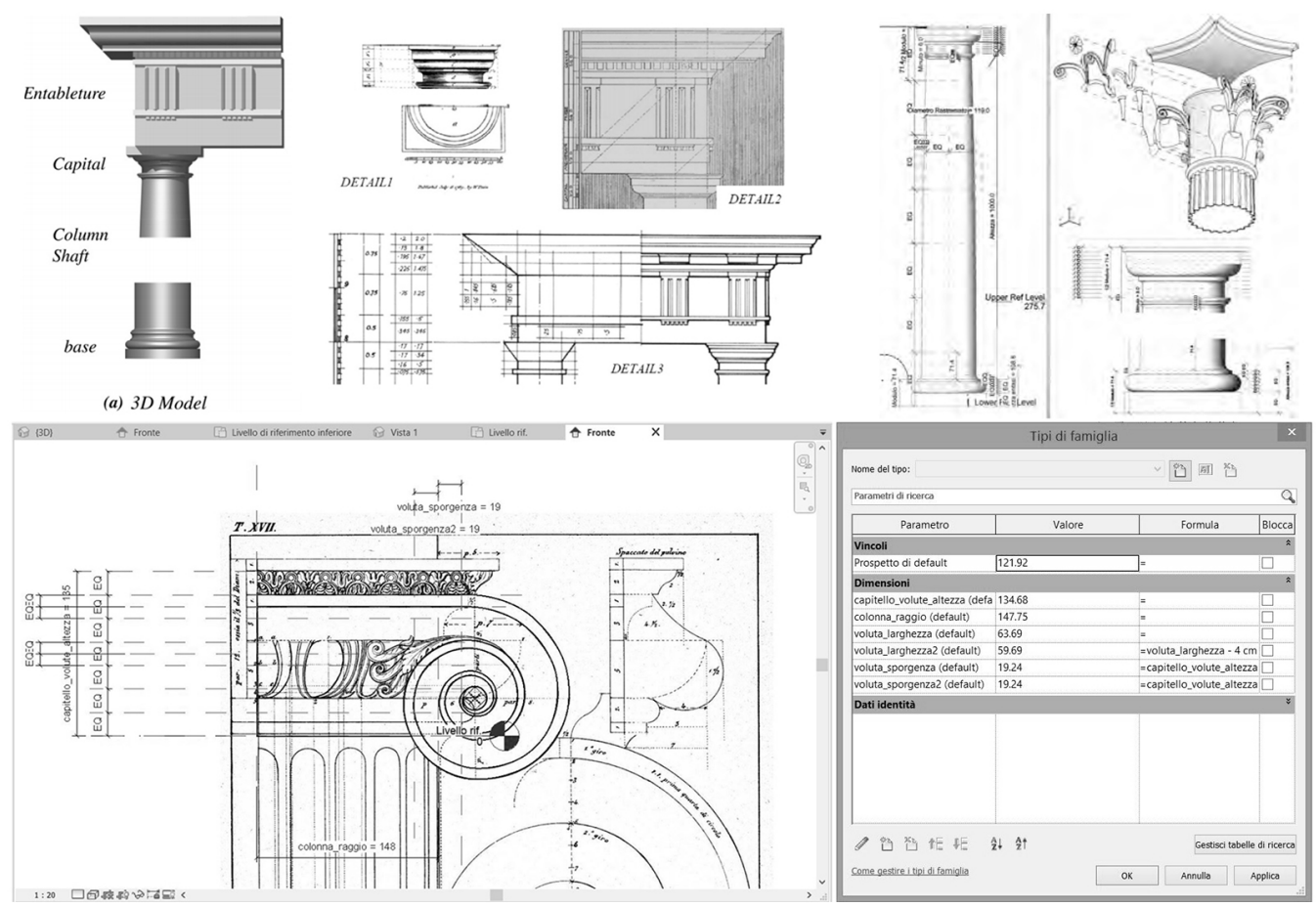
Fig. 2. Proportioning of composite column of the east door the diameter was divided into 2 modules in turn were divided nto 18 part n this proportioning the parameters for the modeling of the order have been set.
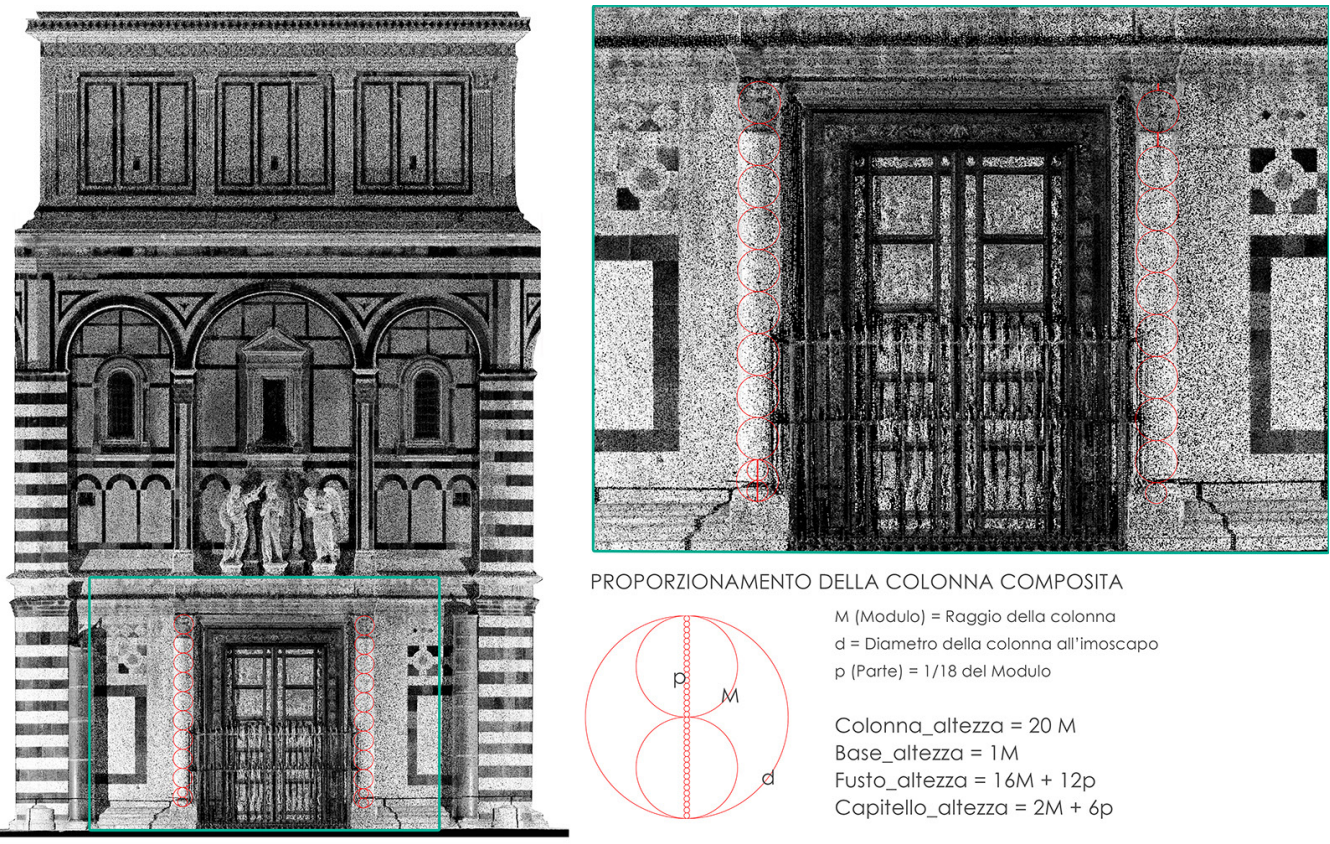

PROPORZIONAMENTO DELLA COLONNA COMPOSITA

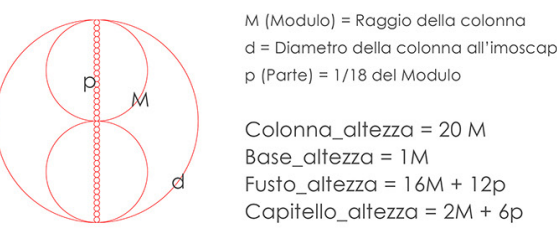

ment of all the elements that make it up, maintaining the same proportional relationships. In the example shown in fig. 2, we proceeded with the proportional analysis of the composite column on the sides of the east gate, known as the Paradise. Having measured the diameter of the column at the imoscapo, it was decided to use the radius of the column
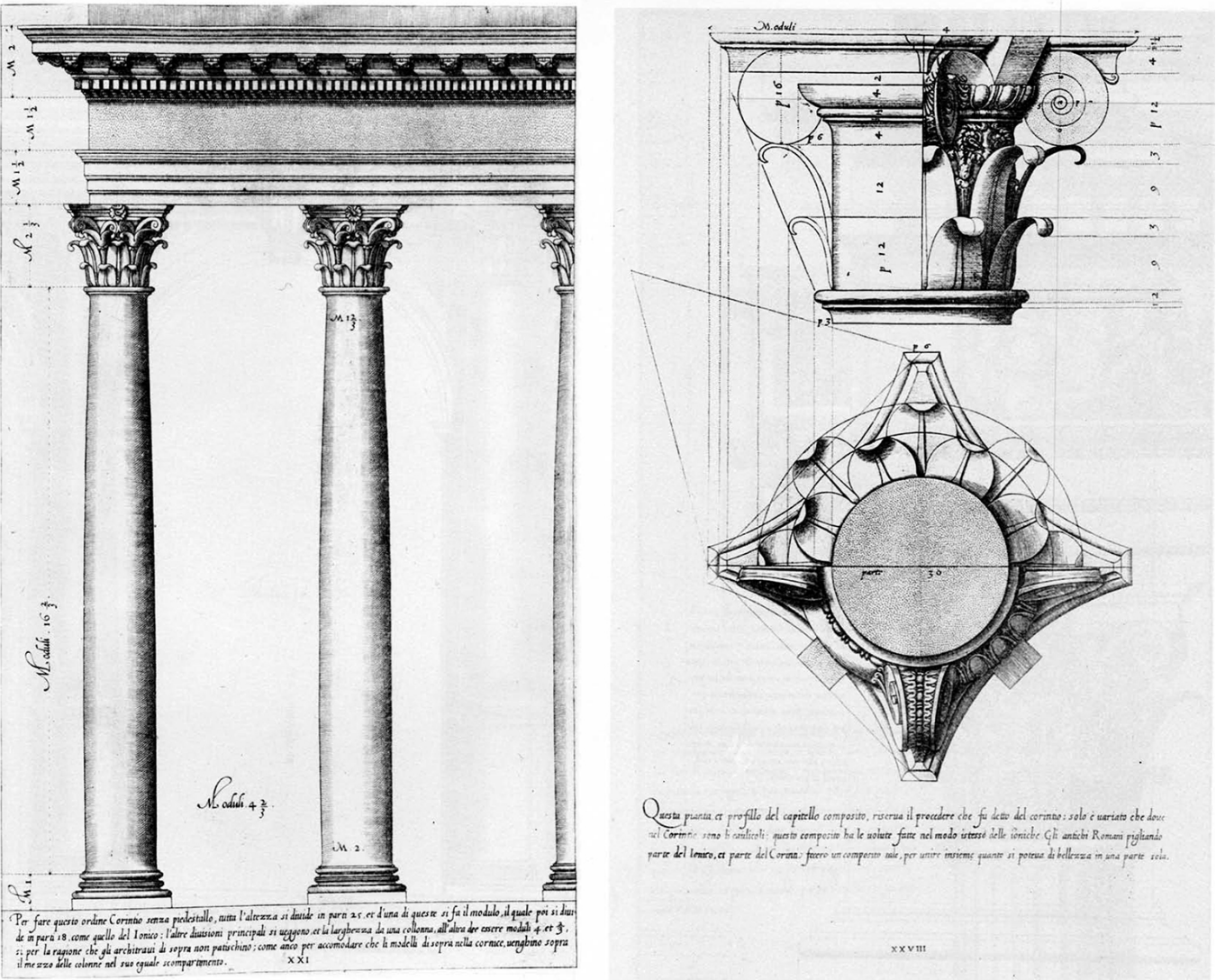
as the module and it was immediately highlighted that the height of the column was equal to 20 modules ( 10 diameters) as defined by the Vignola rule (Regola, tab. XXI and XXVIII) (fig. 3). The module was therefore divided into 18 parts, and it was thus possible to find confirmation in the proportioning of even the smallest parts, such as the collar and the height of the abacus. At this point the proportional analysis has been translated into the setting of the parameters in the modeling of the composite column. First, the 'column radius' parameter was defined equal to I/20 of the height of the column; then it was established that the height of the base was equal to the column radius, our module; later, the 'part' parameter was defined as $1 /$ I 8 of a radius column. This last parameter also allowed the modeling of acanthus leaf decorations and smaller elements, such as collar and abacus; the height of the shaft alone is equal to the formula $16 \times$ column radius +12 $\times$ part, or 16 modules and 2/3.

All the parameters inserted to form the generating formulas of the modeling are instance parameters, as they are linked by a close relationship with the instance parameter 'height' of the metric column. The same argument was made for all the columns, pilasters and pillars present on the facades of the monument, identifying the relationships between the parts to define the parameters of the construction (figs. 4, 5). Also, for loadable families, as is usually done within a new project, it is important to define the reference planes, but above all the dimension annotations between them, since they allow you to link the distances to the parameters entered, and also act as a reference to house other loadable families such as, for example, the generic metric models. The "generic metric model" loadable families allow the modeling of loadable metric objects both within the project and within other loadable families. Specifically, they were used for the parametric modeling of the volutes, both ionic and composite, but also for other decorative elements of the capitals. The attic base, on the other hand, for all types of column or pillar was first modeled as

Fig. 4. Modeling of the vertical support elements: modeling and setting of the composite column parameters, and of the octagonal column-pillar of the second register with composite capital. The setting of the The setting of the f derives from the estinate derives from the estimate proportioning of the
modular elements.

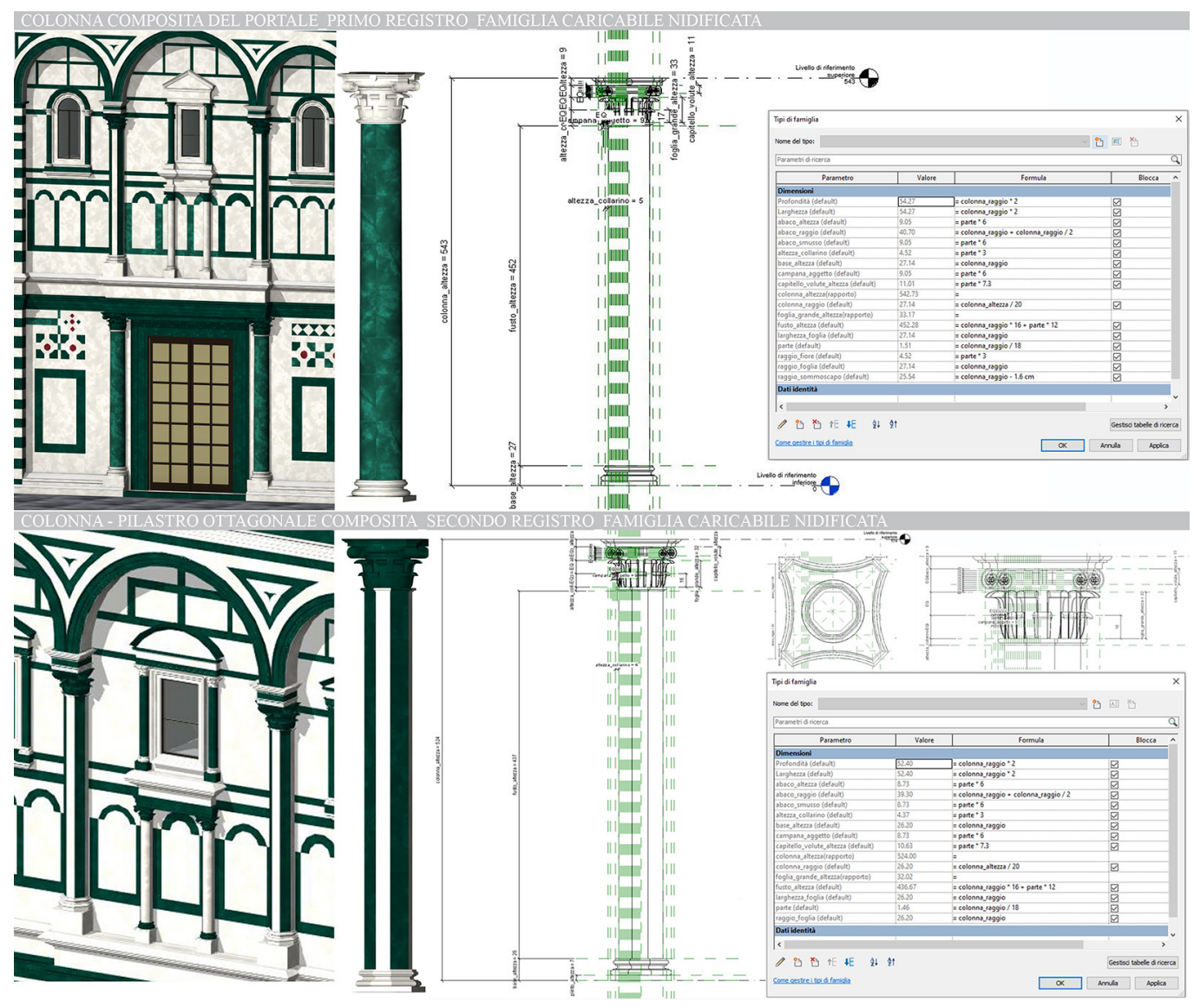


Fig. 5. Modeling of the lonic column on the sides of the arched windows. The nested family houses the Attic basic metric profile family and the Generic metric model of the volute.

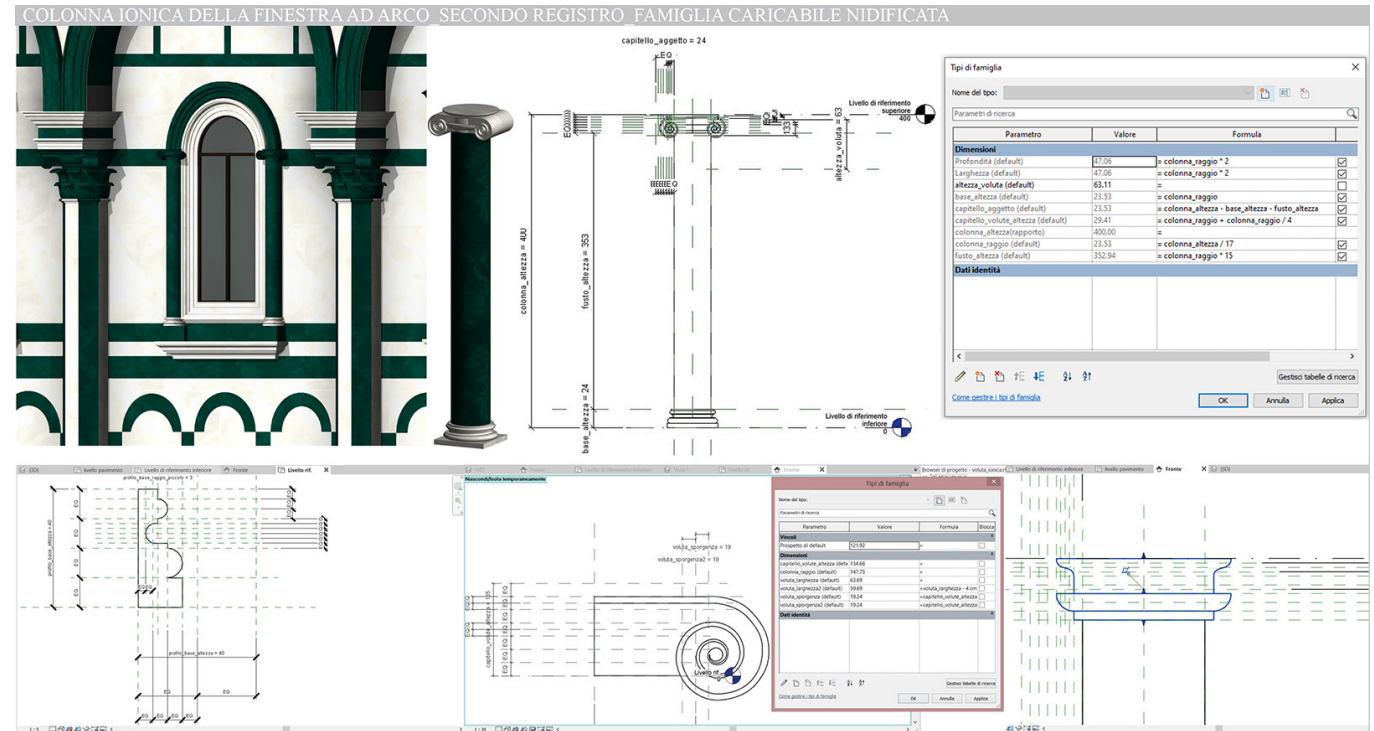

a metric profile family and then extruded within the reference loadable family. Both in the metric profile families and in the generic metric models that are to be loaded into families, it is necessary to model with the type parameters, since, during the import phase into the family, they must be linked and constrained to other instance parameters already present. Particular attention will be paid to standardizing the units of measurement used, both in the project and in the families that can be loaded. In modeling the metric profile of the Attic base, the type of parameter that has been hooked to the column family is the height of the base, which in the loadable family is an instance parameter linked to the radius of the column (fig. 6). Similarly, in the generic volute model, the volute height parameter is linked to the same instance parameter in the loadable family. When modeling a metric element, it is always advisable to specify that this is based on a work plane, as it facilitates the insertion of the object into the loadable family of the relative reference plane. A similar procedure was used for modeling the abacus of composite, Corinthian and lonic capitals, with the only exception of the profile to be extruded, which was modeled directly within the specific family using the extrusion or revolution command. The same goes for the modeling of the decorative parts of the capital such as the acanthus leaves, which have been modeled directly within the specific family as extrusion, as they are linked to the single configuration.

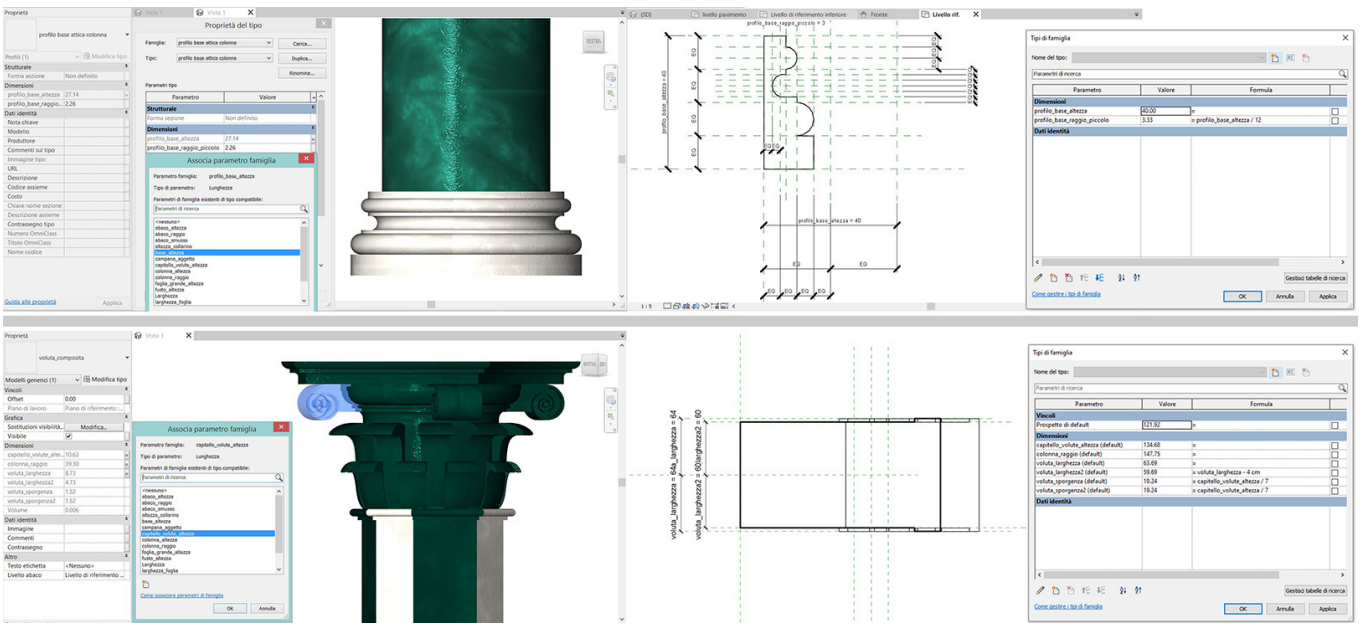

Fig. 6. Modeling of the attic base and volute, and subsequent association those present in the column and pillar family. The association ar the The association of the parameters allows the of the column ensuring the adaptation of these elements as well. 
Fig. 7. Modeling of the entasis of the column according to the

Palladio's procedure. Left: graphic illustration of the procedure drawn by Riccardo Migliari [Migliar |99|, p. 56].
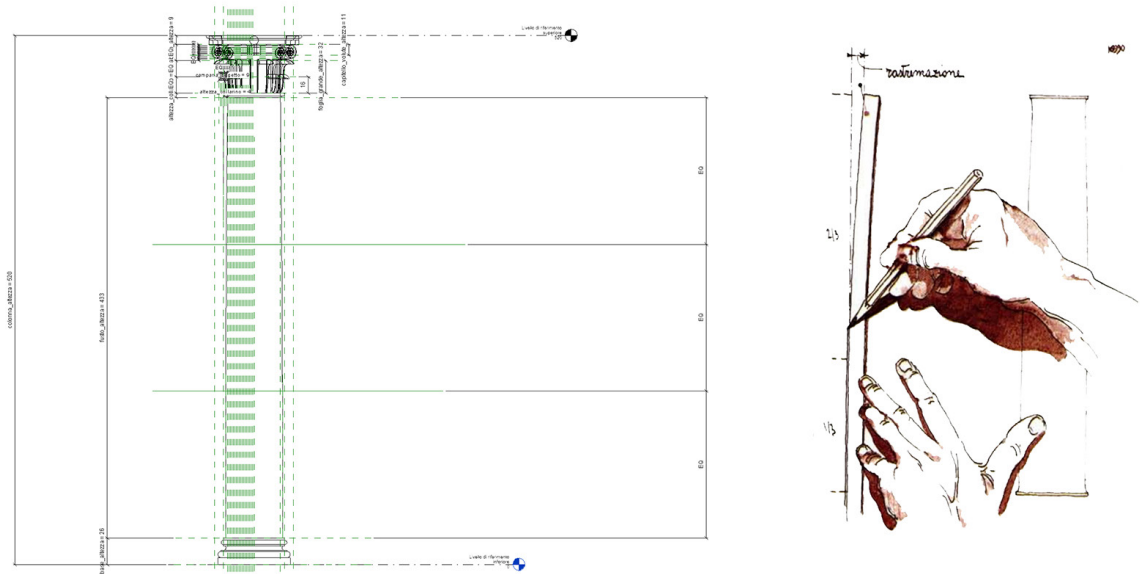

\section{The shaft tapering or èntasis}

The shaft of the column in the architectural order generally undergoes a tapering, or a gradual narrowing starting from about I/3 of the height, up to measuring 5/6 of the diameter at

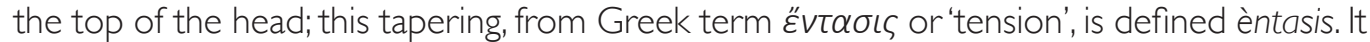
is an optical device that highlights the strength of the member by representing the state of tension of the column that reacts to the compression to which it is subjected. Many Renaissance treatise writers describe the geometric procedure for the geometric representation of the entasis, from the more intuitive one of Palladio, which has its roots in the practice of construction site [Migliari 1991, p. 56], to the geometric one of Vignola and Chitham. For the parametric modeling of the tapering of the composite columns of the portal, Palladio's method was applied, which is quite practical and well suited to parametric logic.

"I part the shaft of the column into three equal parts, and I leave the third part from the bottom straight to plumb, alongside the end of which I place a thin line somewhat long as the column or a little more, and I move that part that advances from the third, and I twist it until its head reaches the point of decrease above the column under the collar; and according to that curvature I sign, and so the column is somewhat swollen in the middle, and it tapers very gently" [Migliari R. 1991, p. 56].

In the same way, the shaft of the column was divided into three equal parts with the help of the reference planes and the usual annotations and an extrusion by revolution of the shaft was generated. In this case, the software asks us to determine the contour lines, or the profile to be extruded, and the centerline, or the axis of revolution. Knowing the diameter of the column at the base and at the top, a contour line anchored to the lower and upper reference planes of the shaft is defined, and a straight line for the first third of the profile of the column; a tangent arc is then constrained to this which allows the tapering to be represented. The profile thus formed is extruded by revolution along the long axis of symmetry of the column. Having constrained the lower and upper planes of the shaft, related to the parameters of the column radius at that point, by changing the height of the column, the entasis fits perfectly (fig. 7). This operation allows you to model the entasis of the shaft of the column through a perfect fitting operation with the point cloud. A further procedure may be to follow the geometric construction proposed by Vignola and Chitham. Specifically, the method provides that the height of the column, fixed the diameter, is divided into three equal parts, and that the entasis concerns $2 / 3$ of this, while the first third remains cylindrical. We describe a semi-circumference at the height of the first third of the shaft; we divide the upper 2/3 of the shaft into a chosen number of equal parts, we establish the diameter at the top and project parallel axes from the extremes of the diameter until meeting the semicircle at the base of the entasis. An arch therefore comes off on the semicircle, which will be divided by the same number of equal parts with which 2/3 of the stem are divided. From these parts, straight lines extend parallel to the axis which, when they meet the corresponding perpendiculars, identify the points through which the tapering curve passes (fig. 8). Note that, although Vignola and others propose a 

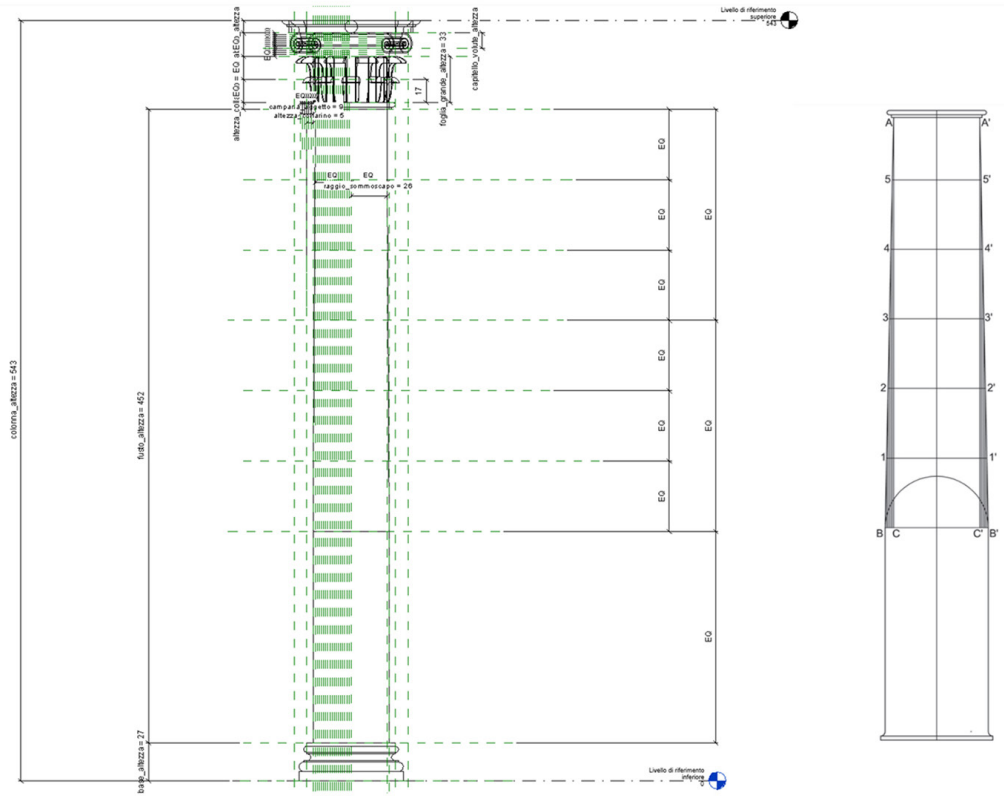

different taper construction for Corinthian or composite columns, in this case the tapering adopted for Tuscan or composite columns was found in the columns of the Baptistery, which provides for tapering only towards the sommoscapo. At this point there are two ways to achieve the tapering of $2 / 3$ of the shaft: in the first case it is possible to join the points through which the curve passes with a spline, or to assimilate the curve described to an elliptical arc that can be modeled inside the BIM platform. In the first case it should be known that by using the spline, the control points allow to approximate well a curve passing through the six points; moreover, by leaving the ends of the curve free from constraints, it adapts perfectly to changes in the height of the column. In the second case, it is necessary to refer to the mathematical and geometric construction of the ellipse as described by Paul Aubin [Aubin 2019] [2]: to construct an ellipse in the Cartesian plane we need to refer to the canonical equation, that is $x^{\wedge} 2 / b^{\wedge} 2+y^{\wedge} 2 / a^{\wedge} 2=1$.

In our case, we have three of the values required to solve the formula: the sum of the six equal parts is the height of the entasis which in the standard formula represents $y$; the radius of the column at the imoscapo is equivalent to the minor axis of ellipse $b$; the radius of the column at the top of the head is equal to $x$. Therefore, our equation becomes $a=\sqrt{ } y^{\wedge} 2 /\left(I-x^{\wedge}\right.$ $2 / b^{\wedge} 2$ ), where $a$ is the semi-major axis of the ellipse. By coding this formula in a language understandable to the software, we impose that the semi-major axis parameter must follow the formula: sqrt $\left(\left(\right.\right.$ entasis $\left.^{\wedge} 2\right) /(1-($ sumpscap radius $` 2) /($ radius column ^ 2$))$ [3].

It is therefore possible to extrude the elliptical arc profile for $2 / 3$ of the shaft and a cylinder for the first third. In this way the entasis of the column becomes parametric in all respects as it is linked to instance parameters already expressed in the family (fig. 9).

\section{Conclusions}

If we think of the Vitruvian procedure of representation of the architectural order by successive partitions, expertly illustrated by Migliari [Migliari R. 199I], it is divided into three main levels, intimately related to the Vitruvian triad of firmitas, utilitas and venustas; these levels are the Constructive Level, about the large masses and the first proportioning, the Functional Level, which instead includes the smaller parts, generated by division of the other elements, and finally the Decorative Level, in which each element is completely modeled by means of the juxtaposition and proportioning of the moldings. This is where each order is characterized (fig. I0). In fact, even for the parametric modeling of 
Fig. 9. Modeling of the column entasis according to the parametric elliptical arc procedure.

Fig. 10. The three levels of decomposition of the architectural order as architectural order as Migliari in the article I igliari in the article disegno degli ordini e il rilievo dell'architettura classica: Cinque Pezzi
Facili from 1991. Graphic reworking by the author

Fig. I I. Decomposition of the architectural parts of a podium according to the Vitruvian classification interpreted by Migliari.
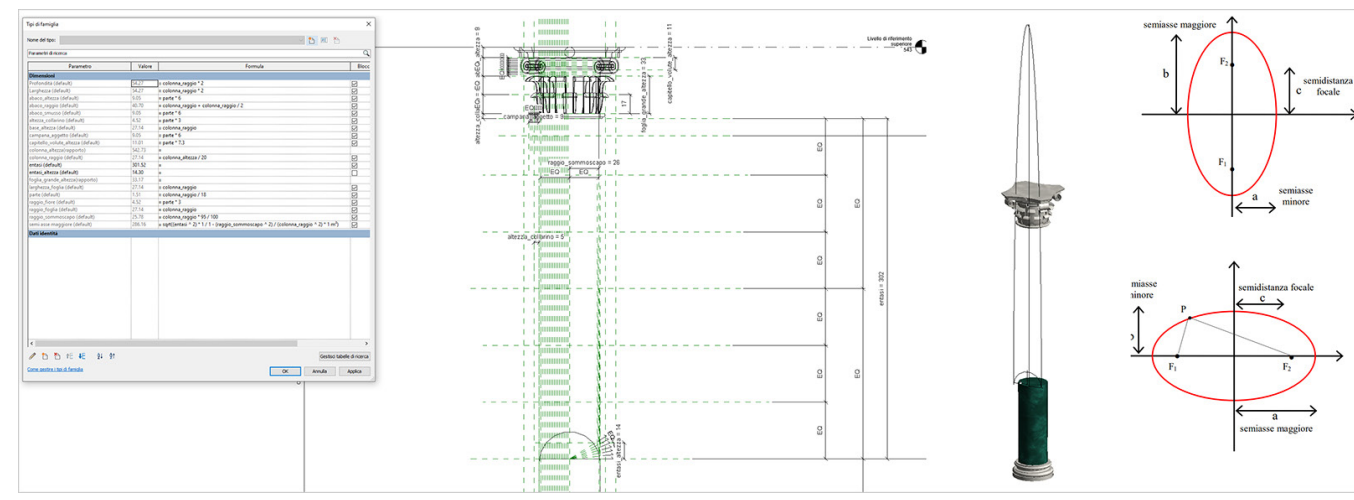

the elements, this three-level decomposition seems to be consistent [Potestà, Bianchini 2020]. In this case, as Migliari describes, there would be a low, constructive level, in which only the large masses, the structural and essential parts appear; a subsequent level in which all the functional parts of the architectural element are represented, a third and last level in which the decorations are also outlined, and the element assumes its complete appearance (fig. I I).

Summarizing the useful and necessary steps for modeling the architectural order in parametric form, we realize that the geometric proportional analysis of the architectural element analyzed is undoubtedly at the base. In setting the parameters there is immediately the awareness that
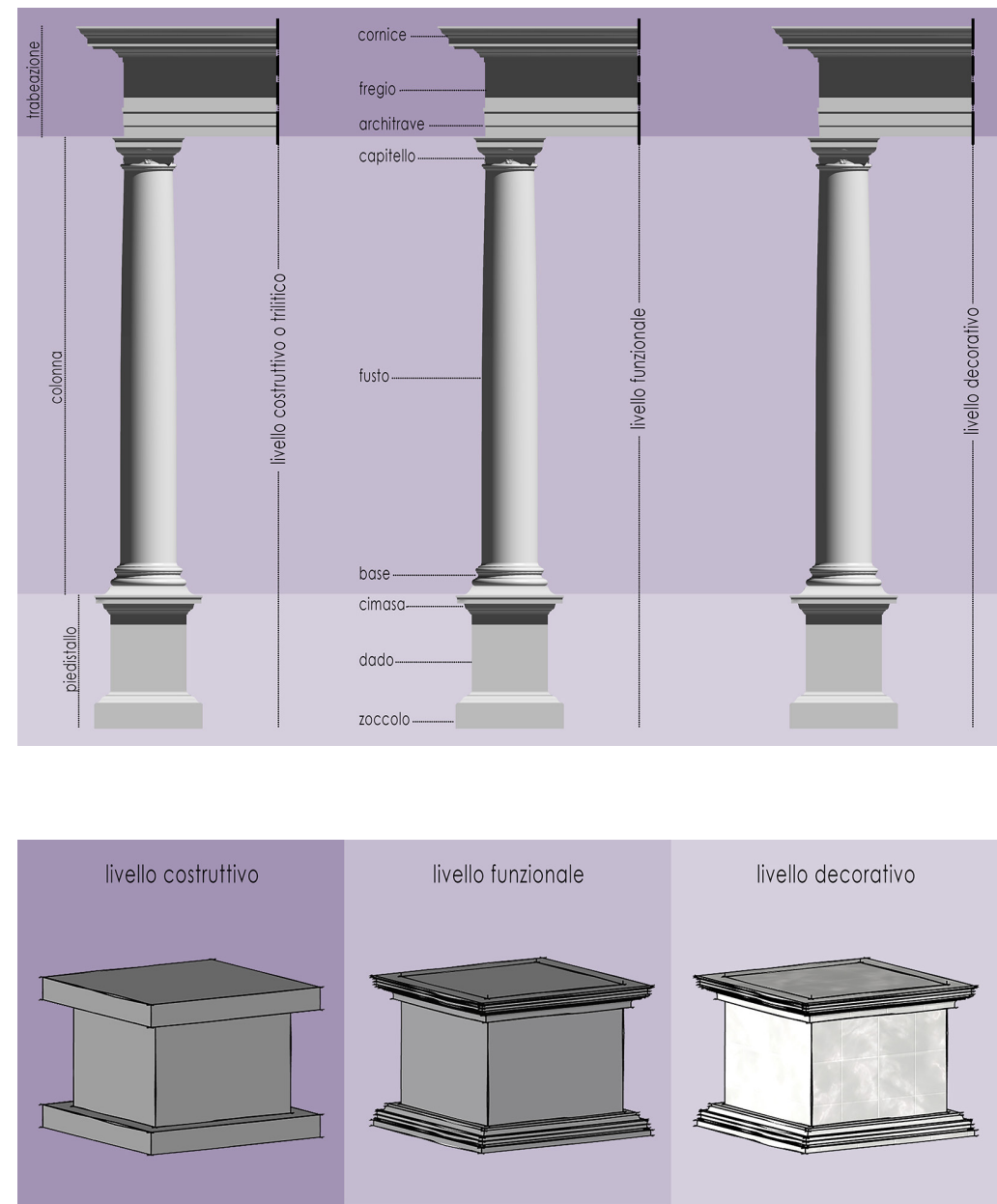
each element must be linked to the others by reciprocal relationships and constraints, that the modification made to an element immediately changes everything in proportional terms, and that everything is governed by close relationship between diameter (or width) and height. The concept of module, as already said, is closely linked to the modern concept of parameter; it is a question of identifying the rule underlying the whole.

The effort required of the operator who models the order, or more generally the historical architecture, is precisely that of reading the proportional ratios used in the architecture and identifying the logic and proportional hierarchies to be able to represent it in the correct way. The Renaissance treatise writers tried to make the same effort, convinced that they could represent the architectural order according to a 'rule'.

\section{Notes}

[I] De Architectura libri decem (The ten books of architecture) is the oldest architectural treatise, and the only one dated before the birth of Christ that has survived in its entirety. In addition to providing us with valuable information on the works and architectural principles of antiquity, it is also the reference text for all architectural theories starting from the Renaissance. Probably written in the second or third decade a. C., the treatise is dedicated to the emperor Augustus, and is the work of a military engineer of the Roman army known as Gentile Vitruvio. During the Middle Ages the text was handed down in numerous manuscripts, however losing its main role in the construction practice; it is only in the fifteenth century with Leon Battista Alberti that an exemplary model is recognized in it and becomes a reference text. Thus it becomes one of the most important treatises of the modern era and between the fifteenth and sixteenth centuries numerous illustrated editions are made, edited by great personalities such as Serlio, Palladio, Vignola, which make Vitruvius' theory popular and applicable.

[2] This procedure was adopted by Paul Aubin in modeling the shaft of the column and described in the volume Renaissance Revit using the method described by Chitham.

[3] If the software detects the "non-homogeneous unit of measurement" error, it is necessary to multiply or divide by I.

\section{References}

AA.V. (20I I). Teoria dell'architettura: 89 trattati dal Rinascimento ad oggi.Voll. II. Köln:Taschen Biblioteca Universalis.

Apollonio F. I., Gaiani M., Sun Z. (2013). 3D modeling and data enrichment in digital reconstruction of architectural heritage. In The International Archives of the Photogrammetry, Remote Sensing and Spatial Information Sciences, XXIV International CIPA Symposium. Strasbourg 2-6 September 2013, volume XL-5/W2, pp. 43-48.

Aubin F.P. (20I3). Reinassance Revit. Creating classical architecture with modern software. Oak Lawn: G3B Press.

Bossalino F. (2002). De Architettura libri X. Bologna: Kappa Edizioni.

Cassa di Risparmio diVignola (Ed.) (1974). Regola delli cinque ordini d'architettura di M. lacomo Barozzio da Vignola. Bologna:Arti Grafiche Tamari.

Migliari R. (199|). Il disegno degli ordini e il rilievo dell'architettura classica: Cinque Pezzi Facili. In Disegnare Idee Immagini, anno II, vol. 2, pp. 49-66. Roma: Gangemi Editore.

Murphy M., MC Govern E., Pavia S. (2013). Historic Building Information Modelling - Adding intelligence to laser and image-based surveys of European classical architecture. In ISPRS Journal of Photogrammetry and Remote Sensing, 76, pp. 89- I02.

Novello G., Lo Turco M. (20 16). La tridimensionalità dell'Architettura e la sua Rappresentazione: un ponte sospeso tra le interpretazioni dei trattatisti italiani del XVI secolo e le metodologie di elaborazione della contemporaneità. In Ega el arquitecto, de la tradición al siglo XXI,Tomo I, pp. I24|-1250.

Paolucci A. (1994). Il battistero di San Giovanni a Firenze. Modena: Cosimo Panini Editore.

Potestà G., Bianchini C. (2020). BIM for built cultural heritage: semantic segmentation, architectural stratification and LOD of the Baptistery of San Giovanni in Florence. In Bolognesi C., Villa D. (Ed.). From Building Information Modelling to Mixed Reality, Springer Tracts in Civil Engineering, pp. I- I5. Cham: Springer.

\section{Author}

Giorgia Potestà, Sapienza Università di Roma, giorgia.potesta@uniromal.it

To cite this chapter. Potestà Giorgia (2021). Modellazione BIM parametrica e Trattati: analogie nella rappresentazione dell'ordine architettonico/ Parametric BIM Modeling and Treatises: Analogies in the Representation of the Architectural Order. In Arena A., Arena M., Mediati D., Raffa P. (a cura di). Connettere. Un disegno per annodare e tessere. Linguaggi Distanze Tecnologie. Atti del $42^{\circ}$ Convegno Internazionale dei Docenti delle Discipline della Rappresentazione/Connecting. Drawing for weaving relationship. Languages Distances Technologies. Proceedings of the 42th International Conference of Representation Disciplines Teachers. Milano: FrancoAngeli, pp. 2587-2606. 